\title{
Diet, feeding behaviour and trophic activity of the anchovy (Engraulis encrasicolus L.) in the Gulf of Lions (Mediterranean Sea)
}

\author{
Serge PLOUNEVEZ ${ }^{\text {a*}}$, Gisèle CHAMPALBERT ${ }^{\text {b }}$ \\ ${ }^{a}$ Laboratoire d'océanographie et de biogéochimie, Centre d'Océanologie de Marseille, \\ rue de la Batterie-des-Lions, 13007 Marseille, France \\ ${ }^{\mathrm{b}}$ Institut de Recherche pour le Développement, BP 917, Abidjan 15, Côte d'Ivoire
}

Received 2 February 1999; revised 13 December 1999; accepted 5 January 2000

\begin{abstract}
Feeding behaviour of adult European anchovy (Engraulis encrasicolus) was studied in the Gulf of Lions (northwestern Mediterranean Sea) in relation to major abiotic and biotic factors. Observations were made during the main spawning period (summer) for two years, data were collected through hydrological profiling, zooplankton hauls and fish trawling performed in areas of high anchovy density. Temperature, salinity and zooplankton biomass were stratified in the study areas, with cladocerans numerous above the thermocline whereas copepods were dominant below. Engraulis encrasicolus was strictly zooplanctivorous during the main spawning season with copepod and crustacean larvae dominating in stomach contents. Anchovy exhibited high trophic activity during the day when they were below the thermocline, with food ingestion equivalent to about $4 \%$ wet body weight per day. Anchovy in the Gulf of Lions employ two feeding modes: selective on large prey and filter-feeding mechanism on small prey. (C) 2000 Ifremer/CNRS/IRD/Éditions scientifiques et médicales Elsevier SAS
\end{abstract}

anchovy / feeding / zooplankton / spawning / Mediterranean Sea

Résumé - Régime, comportement et activité trophique de l'anchois (Engraulis encrasicolus L.) dans le golfe du Lion (Méditerranée). Le comportement trophique de l'anchois adulte (Engraulis encrasicolus) a été étudié dans le golfe du Lion (nord-ouest de la Méditerranée) en relation avec les facteurs environnementaux. Les observations ont été réalisées pendant la période majeure de reproduction (été) de deux années successives. Des profils hydrologiques, des pêches zooplanctoniques et des chalutages ont été effectués dans des zones caractérisées par de fortes densités d'anchois. La colonne d'eau est stratifiée en température, salinité et biomasse zooplanctonique, avec les cladocères nombreux au-dessus de la thermocline et les copépodes dominants au-dessous. L'anchois est strictement zooplanctonophage pendant la période majeure de reproduction se nourrissant essentiellement de copépodes et de larves de crustacés. Les anchois présentent une activité trophique importante au cours de la journée, lorsqu'ils se trouvent au-dessous de la thermocline, avec une ingestion de nourriture d'environ $4 \%$ du poids frais de leur corps. Dans le golfe du Lion, l'anchois utilise deux types de mécanismes alimentaires: sélection sur les proies de grande taille et filtration sur les proies de petite taille. (C) 2000 Ifremer/CNRS/IRD/ Éditions scientifiques et médicales Elsevier SAS

anchois / alimentation / zooplancton / reproduction / Méditerranée

\footnotetext{
*Correspondence and reprints: plounevez@com.univ-mrs.fr
} 


\section{INTRODUCTION}

Anchovies (Family Engraulidae) are frequently the dominant pelagic fish species in coastal upwelling systems around the world and the economical importance of their fishery is well known (see reviews [2, 5]). But anchovies are also present in some less productive regions where their fishery is relatively important, for example Engraulis encrasicolus in European seas: the catch ranges between 181000 tons and 636000 tons according to the year [15].

In the Gulf of Lions, located in the Mediterranean Sea between $42^{\circ} 15^{\prime} \mathrm{N}$ and $43^{\circ} 35^{\prime} \mathrm{N}$ latitude and $3^{\circ} \quad 00^{\prime} \quad \mathrm{E}$ and $6^{\circ} \quad 00^{\prime} \mathrm{E}$ longitude along French coasts and covering an area of 3661 square nautical miles with a large continental shelf, the French anchovy fishery ranks second or third in catch (6000-10000 tons) as well as in economical value (60-70 million FF) according to the year.

Nevertheless, in the northwestern Mediterranean Sea, studies on anchovy ecology are limited to the Catalan Sea: most concern egg and larvae distributions and feeding of larvae [38-40]; data on adult feeding remain few [44, 45]. In the Gulf of Lions, the only information about anchovy concerns spawning, which mainly occurs in summer and peaks in July [1, 28].

Studies on the feeding behaviour of adult anchovies performed on many species and in different areas showed that whilst tooth phytoplankton and zooplankton are found in anchovy stomachs $[8,9,23$, $25,26,31,32,34,46]$, zooplankton is considered to provide the major dietary input $[8,9,23,26,32,34]$. According to several authors $[4,7,34,44,46]$, anchovy feeding is mainly diurnal, although crepuscular [23] and nocturnal [7] feeding activities have been reported.

The aim of the present paper is to study the respective influences of important abiotic and biotic factors on the feeding behaviour of the European anchovy (Engraulis encrasicolus) in the Gulf of Lions during summer. In particular, the relationships between food availability and feeding and their possible consequences on anchovy distribution in this area are examined.

\section{MATERIAL AND METHODS}

This study was carried out in the Gulf of Lions during two cruises over the continental shelf: PELMED 95 (PM 95) was from 31 July-1 September 1995 and PELMED 96 (PM 96) was from 28 June31 July 1996). Both cruises were conducted aboard the R.V. l'Europe and were divided into two parts (figure 1). The aim of the first part of each cruise was to assess the stock of small pelagic fishes using acoustic methods and continuous observations along regularly spaced (12 nautical miles) inshore-offshore transects. Pelagic trawls were performed to identify target species. The second part of each cruise focused on the ecology of the anchovy. Pelagic trawling, hydrological and zooplankton sampling were performed in specific areas where high densities of anchovy were detected by echosounding: two areas of $5 \times 5$ square miles ( 1 and 2 ) were chosen during PM 95, and two transects (24 and 27) during PM 96 (figure 1).

\subsection{Hydrological data}

Temperature and salinity profiles were recorded with a CTD probe during the second part of each cruise. During PM 95, 14 profiles were performed immediately after trawling at a point situated half-way between the beginning and the end of the trawl. During PM 96, measurements were carried out along two transects; on each transect sampling was conducted at five stations respectively located at $30,60,90,120$ and $200 \mathrm{~m}$ depth (figure 1-transect 24: stations A-E; transect 27: stations $\mathrm{F}-\mathrm{J}$ ).

\subsection{Zooplankton samples}

Along with hydrological profiles, zooplankton was collected with a WP-2 standard net (mesh size $200 \mu \mathrm{m}$ ). At each sampling station, the nets were towed vertically from the bottom of the thermocline to the surface; again from the bottom of the water column to the bottom of the thermocline (net equipped with a closing mechanism). During PM 96 at stations located in $30 \mathrm{~m}$ of water (A and F), a single haul was made from the bottom to the surface. In order to collect small zooplankton, a WP-2 net fitted with 
$80-\mu \mathrm{m}$ mesh was towed vertically from the bottom of the water column to the surface at all stations during PM 96.

On board, zooplankton samples were divided into two batches with a Motoda box; the first one was preserved in liquid nitrogen and the second in $5 \%$ buffered formaldehyde. In the laboratory, samples preserved in liquid nitrogen were dried at $50^{\circ} \mathrm{C}$ for $72 \mathrm{~h}$, and zooplankton dry weight was calculated in $\mathrm{g} \cdot \mathrm{m}^{-3}$. Zooplankton samples preserved in formalin were subsampled by the surface method [6]. Zooplankton samples were poured into a circular flat-bottomed receptacle of know surface. After homogenisation of the sample, three sub-samples delimited by a cylinder whose surface was known were picked out. Each sub-sample (about one thousand individuals) was decanted into a "Dolfuss" bowl. Specimens were sorted into different taxa and identified under a stereo-microscope to group level for ostracods, molluscs, and Mallacostracean larvae (large crustacean) and to species level for cladocerans and copepods except Clausocalanidae, Oithonidae, Oncaeidae, and Corycaeidae which were identified to genus level. The number and the relative abundance of the different taxa were calculated per cubic metre.

\subsection{Fish samples}

The position of anchovy shoals in the water column were detected by echo-sounding (Echo-sounder OSSIAN $^{\circledR} 38 \mathrm{kHz}$ ). Anchovies were collected using a mid-water trawl towed for about one hour between 5 $\mathrm{h}$ and $17 \mathrm{~h}$ (U.T.) during PM 95, and between $4 \mathrm{~h}$ and $22 \mathrm{~h}$ (U.T.) during PM 96 (table I). The night samples were scarce because of rules of the work. Twenty three tows were carried out during each cruise. One kilogram of adult anchovy was sampled at random from every haul and immediately frozen at $-40{ }^{\circ} \mathrm{C}$ to stop digestive processes; later, fish were preserved at $-20^{\circ} \mathrm{C}$ until laboratory analysis. From each kilogram sampled, 15 to 33 adult anchovy were selected at random and the following measurements taken: fish total length (TL) rounded down to the nearest $0.5 \mathrm{~cm}$, fish wet weight (FW, to the nearest $0.001 \mathrm{~g}$ ), gonad wet weight with sex determination $(\mathrm{GW}$, to the nearest $0.001 \mathrm{~g}$ ), wet weight of the actual stomach contents (SW, to the nearest $0.1 \mathrm{mg}$ ). A total of 354 and 503 fish were studied from PM 95 and PM 96 respectively.

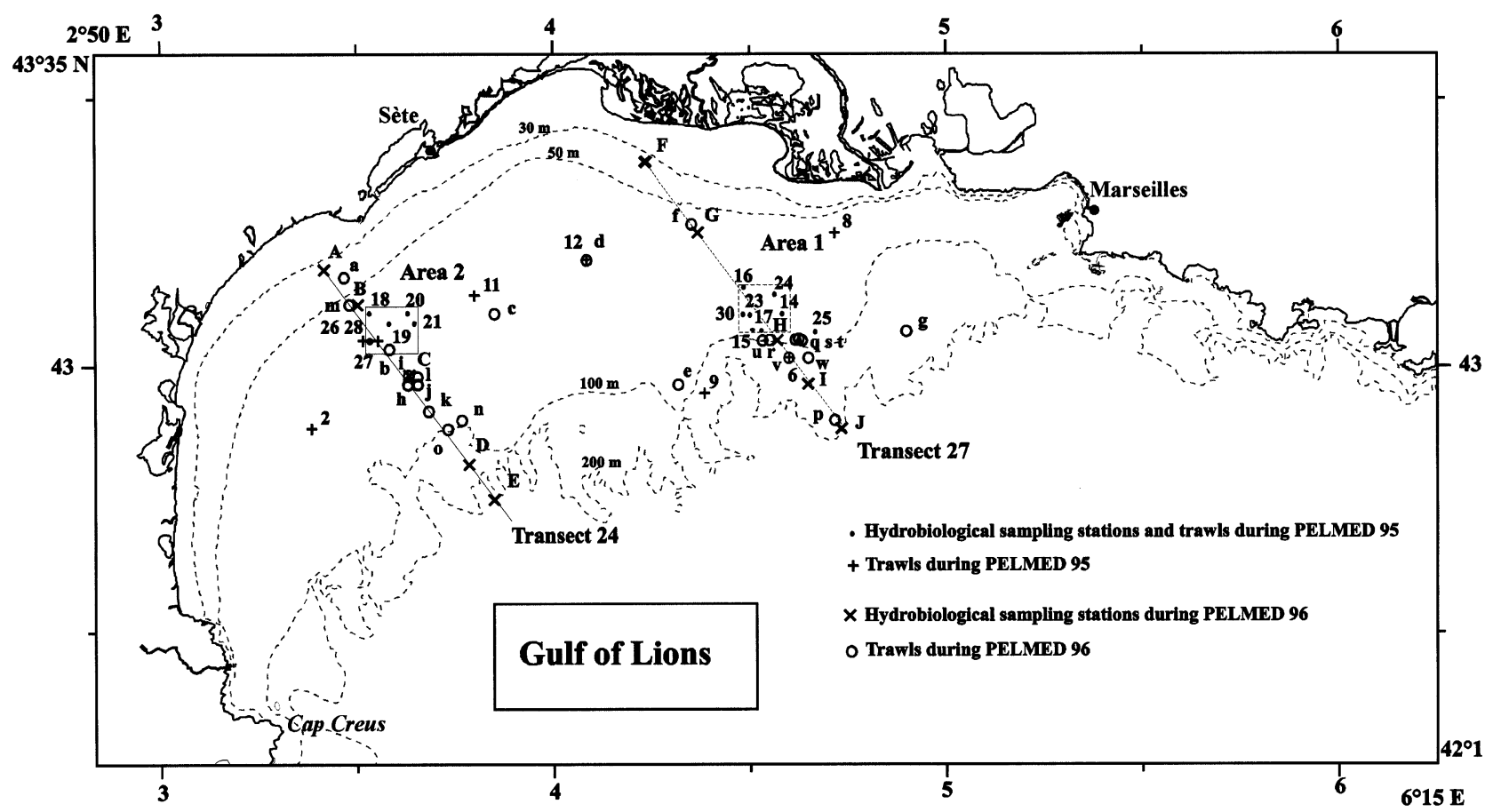

Figure 1. Location of hydrobiological sampling stations and trawls performed during PELMED 95 and PELMED 96. 
Table I. PELMED 95 and PELMED 96. Trawls performed and anchovies analysed ${ }^{\mathrm{a}}$.

\begin{tabular}{|c|c|c|c|c|c|c|c|c|}
\hline Cruise/Date & $\begin{array}{l}\text { Trawling } \\
\text { number }\end{array}$ & $\begin{array}{l}\text { Initial time of } \\
\text { catch (U.T.) }\end{array}$ & Latitude north & Longitude east & Initial depth $(\mathrm{m})$ & $\begin{array}{l}\text { Trawling } \\
\text { duration (h) }\end{array}$ & $\begin{array}{l}\text { Average of } \\
\text { length fish } \\
(\mathrm{cm}) \pm \mathrm{SD}^{\mathrm{a}}\end{array}$ & $\begin{array}{l}\text { Individuals } \\
\text { number }\end{array}$ \\
\hline $\begin{array}{l}\text { PELMED } 95 \\
31 / 07 / 95 \\
10 / 08 / 95 \\
10 / 08 / 95 \\
11 / 08 / 95 \\
12 / 08 / 95 \\
13 / 08 / 95 \\
15 / 08 / 95 \\
15 / 08 / 95 \\
16 / 08 / 95 \\
16 / 08 / 95 \\
17 / 08 / 95 \\
18 / 08 / 95 \\
18 / 08 / 95 \\
19 / 08 / 95 \\
23 / 08 / 95 \\
23 / 08 / 95 \\
24 / 08 / 95 \\
24 / 08 / 95 \\
29 / 08 / 95 \\
29 / 08 / 95 \\
30 / 08 / 95 \\
31 / 08 / 95 \\
01 / 09 / 95\end{array}$ & $\begin{array}{l}2 \\
6 \\
8 \\
9 \\
11 \\
12 \\
14 \\
15 \\
16 \\
17 \\
18 \\
19 \\
20 \\
21 \\
23 \\
24 \\
25 \\
26 \\
27 \\
28 \\
29 \\
30 \\
31\end{array}$ & $\begin{array}{l}07: 29 \\
05: 26 \\
15: 16 \\
08: 13 \\
13: 12 \\
08: 17 \\
12: 14 \\
16: 20 \\
05: 18 \\
09: 56 \\
16: 24 \\
08: 49 \\
14: 52 \\
05: 10 \\
06: 03 \\
11: 38 \\
05: 26 \\
16: 11 \\
11: 55 \\
16: 43 \\
14: 13 \\
13: 23 \\
05: 48\end{array}$ & $\begin{array}{lll}42^{\circ} & 53.43^{\prime} \\
43^{\circ} & 01.84 \\
43^{\circ} & 15.60 \\
42^{\circ} & 57.12 \\
43^{\circ} & 08.12 \\
43^{\circ} & 12.66 \\
43^{\circ} & 06.50^{\prime} \\
43^{\circ} & 03.91 \\
43^{\circ} & 09.16^{\prime} \\
43^{\circ} & 03.89^{\prime} \\
43^{\circ} & 06.02 \\
43^{\circ} & 05.94 \\
43^{\circ} & 06.05^{\prime} \\
43^{\circ} & 01.94 \\
43^{\circ} & 05.50^{\prime} \\
43^{\circ} & 09.56 \\
43^{\circ} & 02.83 \\
43^{\circ} & 03.61 \\
43^{\circ} & 03.42^{\prime} \\
43^{\circ} & 03.39^{\prime} \\
43^{\circ} & 03.93 \\
43^{\circ} & 06.48^{\prime} \\
43^{\circ} & 07.93\end{array}$ & 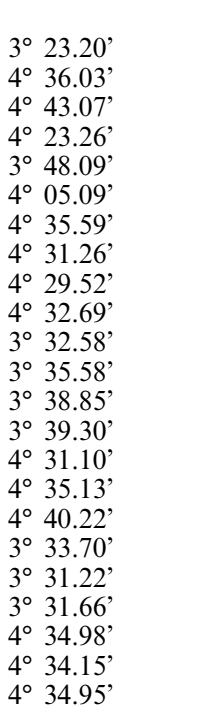 & $\begin{array}{l}91 \\
84 \\
89 \\
89 \\
85 \\
86 \\
80 \\
83 \\
73 \\
90 \\
83 \\
82 \\
90 \\
84 \\
75 \\
82 \\
85 \\
89 \\
86 \\
87 \\
74 \\
79 \\
78\end{array}$ & $\begin{array}{l}1: 00 \\
1: 08 \\
1: 03 \\
1: 23 \\
1: 03 \\
1: 13 \\
1: 28 \\
1: 13 \\
1: 01 \\
0: 55 \\
1: 07 \\
0: 41 \\
1: 07 \\
1: 00 \\
0: 50 \\
0: 56 \\
0: 59 \\
1: 04 \\
0: 57 \\
0: 53 \\
1: 16 \\
1: 04 \\
1: 09\end{array}$ & $\begin{array}{l}13.7 \pm 1.0 \\
12.1 \pm 1.3 \\
12.0 \pm 0.4 \\
13.1 \pm 0.7 \\
12.5 \pm 0.9 \\
12.7 \pm 1.9 \\
10.8 \pm 1.2 \\
12.7 \pm 0.6 \\
11.6 \pm 1.0 \\
13.5 \pm 1.8 \\
12.5 \pm 0.7 \\
12.8 \pm 0.8 \\
12.9 \pm 0.7 \\
12.4 \pm 0.5 \\
10.8 \pm 0.8 \\
10.2 \pm 1.1 \\
13.0 \pm 0.7 \\
10.5 \pm 1.1 \\
10.9 \pm 1.3 \\
11.5 \pm 1.7 \\
13.3 \pm 0.6 \\
15.0 \pm 0.9 \\
12.6 \pm 1.2\end{array}$ & $\begin{array}{l}15 \\
16 \\
15 \\
15 \\
15 \\
15 \\
16 \\
15 \\
15 \\
15 \\
15 \\
18 \\
15 \\
15 \\
15 \\
15 \\
15 \\
16 \\
15 \\
15 \\
15 \\
15 \\
18\end{array}$ \\
\hline $\begin{array}{l}\text { PELMED } 96 \\
12 / 07 / 96 \\
12 / 07 / 96 \\
13 / 07 / 96 \\
14 / 07 / 96 \\
14 / 07 / 96 \\
16 / 07 / 96 \\
17 / 07 / 96 \\
19 / 07 / 96 \\
19 / 07 / 96 \\
20 / 07 / 96 \\
20 / 07 / 96 \\
20 / 07 / 96 \\
24 / 07 / 96 \\
24 / 07 / 96 \\
24 / 07 / 96 \\
25 / 07 / 96 \\
26 / 07 / 96 \\
26 / 07 / 96 \\
27 / 07 / 96 \\
27 / 07 / 96 \\
27 / 07 / 09 \\
29 / 07 / 96 \\
29 / 04 / 96\end{array}$ & $\begin{array}{l}\mathrm{a} \\
\mathrm{b} \\
\mathrm{c} \\
\mathrm{d} \\
\mathrm{e} \\
\mathrm{f} \\
\mathrm{g} \\
\mathrm{h} \\
\mathrm{i} \\
\mathrm{j} \\
\mathrm{k} \\
\mathrm{l} \\
\mathrm{m} \\
\mathrm{n} \\
\mathrm{o} \\
\mathrm{p} \\
\mathrm{q} \\
\mathrm{r} \\
\mathrm{s} \\
\mathrm{t} \\
\mathrm{u} \\
\mathrm{v} \\
\mathrm{w}\end{array}$ & $\begin{array}{l}07: 47 \\
11: 08 \\
08: 55 \\
06: 55 \\
11: 18 \\
10: 29 \\
07: 13 \\
07: 13 \\
16: 38 \\
03: 02 \\
04: 18 \\
06: 33 \\
06: 45 \\
12: 38 \\
16: 26 \\
11: 59 \\
14: 07 \\
16: 06 \\
04: 56 \\
07: 15 \\
08: 47 \\
16: 38 \\
20: 36\end{array}$ & $\begin{array}{ll}43^{\circ} & 10.41 \\
43^{\circ} & 02.26 \\
43^{\circ} & 06.07 \\
43^{\circ} & 12.01 \\
42^{\circ} & 58.90^{\prime} \\
43^{\circ} & 16.20 \\
43^{\circ} & 04.17 \\
42^{\circ} & 58.67 \\
42^{\circ} & 59.01 \\
42^{\circ} & 58.51 \\
42^{\circ} & 55.53 \\
42^{\circ} & 58.75 \\
43^{\circ} & 07.65 \\
42^{\circ} & 54.10^{\prime} \\
42^{\circ} & 53.12 \\
42^{\circ} & 54.31 \\
43^{\circ} & 03.40 \\
43^{\circ} & 03.30 \\
43^{\circ} & 03.23 \\
43^{\circ} & 03.28^{\prime} \\
43^{\circ} & 03.51 \\
43^{\circ} & 01.92 \\
43^{\circ} & 01.05\end{array}$ & $\begin{array}{l}3^{\circ} 28.25, \\
3^{\circ} 35.27, \\
3^{\circ} 51.68, \\
4^{\circ} 05.97, \\
4^{\circ} 19.33, \\
4^{\circ} 21.53, \\
4^{\circ} 54.08, \\
3^{\circ} 38.97, \\
3^{\circ} 38.71, \\
3^{\circ} 39.27, \\
3^{\circ} 41.20^{\circ}, \\
3^{\circ} 38.92, \\
3^{\circ} 29.66, \\
3^{\circ} 46.10, \\
3^{\circ} 44.04, \\
4^{\circ} 43.43, \\
4^{\circ} 37.11, \\
4^{\circ} 33.35, \\
4^{\circ} 38.22, \\
4^{\circ} 38.13, \\
4^{\circ} 32.63, \\
4^{\circ} 36.28, \\
4^{\circ} 39.25,\end{array}$ & $\begin{array}{l}35 \\
84 \\
92 \\
89 \\
87 \\
65 \\
107 \\
95 \\
92 \\
90 \\
92 \\
96 \\
55 \\
102 \\
96 \\
131 \\
92 \\
90 \\
93 \\
91 \\
90 \\
107 \\
106\end{array}$ & $\begin{array}{l}0: 39 \\
0: 36 \\
0: 49 \\
0: 47 \\
1: 21 \\
1: 00 \\
0: 41 \\
0: 58 \\
0: 57 \\
0: 43 \\
0: 38 \\
1: 05 \\
0: 43 \\
1: 06 \\
1: 03 \\
1: 10 \\
1: 00 \\
0: 19 \\
1: 00 \\
1: 00 \\
0: 15 \\
0: 26 \\
0: 55\end{array}$ & $\begin{array}{l}11.2 \pm 0.5 \\
12.9 \pm 0.8 \\
13.0 \pm 0.8 \\
12.2 \pm 0.6 \\
13.2 \pm 1.2 \\
11.8 \pm 0.8 \\
11.2 \pm 0.4 \\
13.2 \pm 1.1 \\
13.4 \pm 0.9 \\
13.0 \pm 0.9 \\
12.6 \pm 0.6 \\
13.2 \pm 0.9 \\
12.4 \pm 1.0 \\
14.5 \pm 1.2 \\
14.4 \pm 1.2 \\
12.4 \pm 0.7 \\
12.6 \pm 0.7 \\
12.5 \pm 0.8 \\
12.8 \pm 0.6 \\
13.5 \pm 1.1 \\
12.9 \pm 0.8 \\
12.8 \pm 0.8 \\
13.0 \pm 0.9\end{array}$ & $\begin{array}{l}12 \\
26 \\
20 \\
15 \\
15 \\
15 \\
20 \\
27 \\
38 \\
04 \\
25 \\
24 \\
28 \\
15 \\
30 \\
28 \\
25 \\
32 \\
26 \\
10 \\
24 \\
27 \\
17\end{array}$ \\
\hline
\end{tabular}

a total length, SD: standard deviation. 
The vacuity index (V) and the stomach fullness index (F) were used to determine feeding activity:

$\mathrm{V}=\frac{\mathrm{E}}{\mathrm{T}} \times 100$

where $\mathrm{E}$ was the number of empty stomachs and $\mathrm{T}$ the total number of stomachs analysed per trawl.

$\mathrm{F}=\frac{\mathrm{SW}}{\mathrm{FW}-\mathrm{GW}-\mathrm{SW}} \times 1000$

Most anchovies had food in stomach throughout the day and the prey were intact or partially digested. Thus, anchovies fed continuously during the day. Therefore, fishes with empty stomachs were not used in the estimation of $\mathrm{F}$. The mean and standard deviation of $\mathrm{F}$ were calculated for each trawl, the "locally weighted regression" [10] was used to determine the effects of anchovy sex and size on the fullness index.

Daily ration was estimated for fish sampled in area 1 during PM 95, for all samples collected during the second part of PM 96, excluding trawls in which the anchovy mean size was much higher than the main mode of the size range observed during the survey.

The exponential model described by Elliott and Persson [14] was used to calculate food consumption during the day:

$\mathrm{C}_{\mathrm{t}}=\frac{\left(\mathrm{F}_{\mathrm{t}}-\mathrm{F}_{\mathrm{o}} \mathrm{e}^{-\mathrm{Rt}}\right) \mathrm{Rt}}{1-\mathrm{e}^{-\mathrm{Rt}}}$

where $C_{t}$ is the amount of food consumed in thours, $\mathrm{R}$ is the instantaneous gastric evacuation rate, $\mathrm{F}_{0}$ and $F_{t}$ are the means of the stomach fullness index of anchovies calculated stepwise from trawl 0 to trawl $t$, then from trawl $t$ to trawl $t+x$. The sum of the partial consumption $\left(\mathrm{C}_{t}\right)$ gives the food consumption over the time interval covered by all trawls. The $\mathrm{R}$ value we used (0.423) came from the Tudela and Palomera [44] estimates on Engraulis encrasicolus from the Catalan Sea. The standard error of $C_{t}$ was calculated according to the Worobec method [49] as suggested by Tudela and Palomera [44].

Prey numbers and specific determination of items found in anchovy stomachs were studied using the same criteria as those chosen for the plankton samples. A total of 526 anchovy were analysed: 279 from PM 95 and 247 from PM 96.

The index of preponderance $\left(\mathrm{I}_{\mathrm{i}}\right)$ [33] was used to characterize the feeding habits of anchovy:

$$
\begin{aligned}
& \mathrm{I}_{\mathrm{i}}=\frac{\mathrm{M}_{\mathrm{i}} \times \mathrm{O}_{\mathrm{i}}}{\sum_{\mathrm{i}=1}^{\mathrm{p}}\left(\mathrm{M}_{\mathrm{i}} \times \mathrm{O}_{\mathrm{i}}\right)} \\
& \left(0<\mathrm{I}_{\mathrm{i}}<1 \text { and } \sum_{\mathrm{i}=1}^{\mathrm{p}} \mathrm{I}_{i}=1\right)
\end{aligned}
$$

where Mi is the ratio (in percent) of the weight of the prey $i$ to the weight of all the prey items and Oi is the occurrence of the prey $i$.

The index of preponderance was calculated for anchovies from each area in PM 95 and from each transect in PM 96. The index was a "mixed method" to analyse the diet of the fish. Prey items were ranked according to the product of their weight in the stomach and the frequency with which that item occurred. Hence, this index avoided the positive bias towards small but frequently-encountered prey items (such as small copepods) inherent in the numerical method and also avoided positively biasing large and infrequently-found prey items (such as fish larva) which would be the case if only the gravimetric method was used. The index of preponderance therefore provided a hierarchy of the relative importance of prey items with the most important ones having the highest values.

The graphical method of Costello [11] provides a representation of the percentage weight versus the frequency of occurrence of dominant prey items, and was used to determine the feeding behaviour of anchovy according to their length. The distribution of anchovy length was of the Gauss type for both years, and anchovies of the upper and lower length classes were clustered to obtain approximately similar number of individuals in each group. Five length classes $(11.5 \mathrm{~cm}, 12.0 \mathrm{~cm}, 12.5 \mathrm{~cm}, 13.0 \mathrm{~cm}, 13.5 \mathrm{~cm})$ were defined for PM 95 and six $(11.5 \mathrm{~cm}, 12.0 \mathrm{~cm}, 12.5 \mathrm{~cm}$, $13.0 \mathrm{~cm}, 13.5 \mathrm{~cm}, 14.0 \mathrm{~cm}$ ) for PM 96.

Prey dry weights used in the index calculations were measured in the laboratory for the dominant copepod species, fish larvae and crustacean larvae. Sets of Microsetella rosea, Temora stylifera and Candacia 
PELMED 95
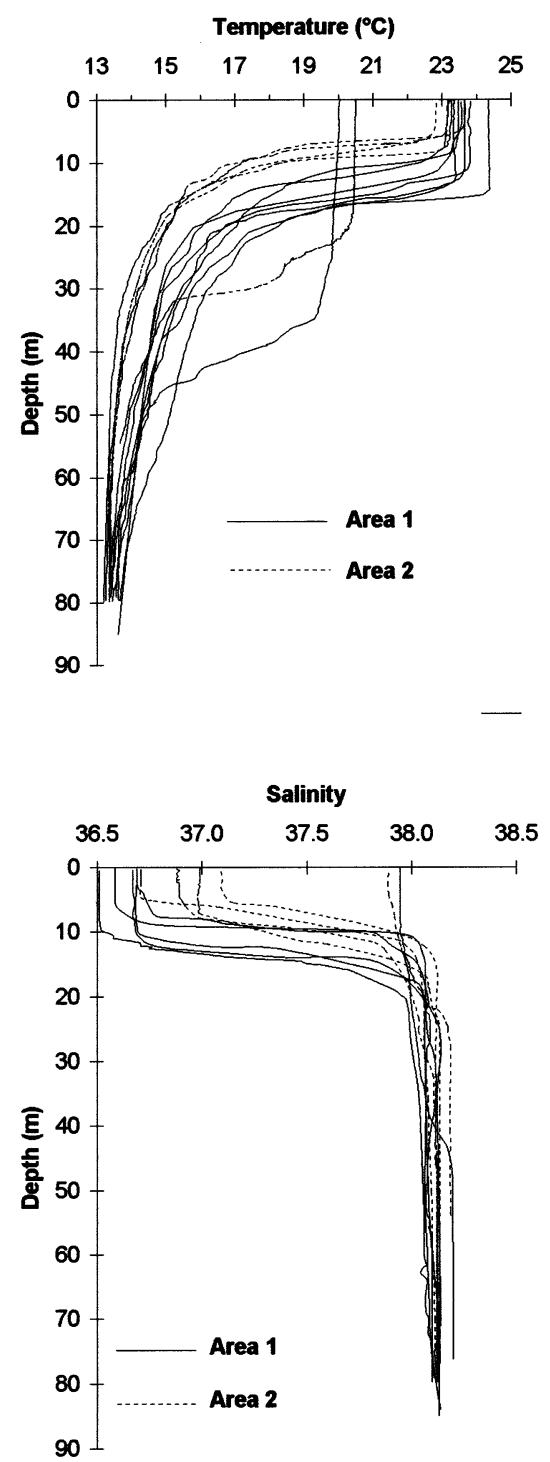

PELMED 96
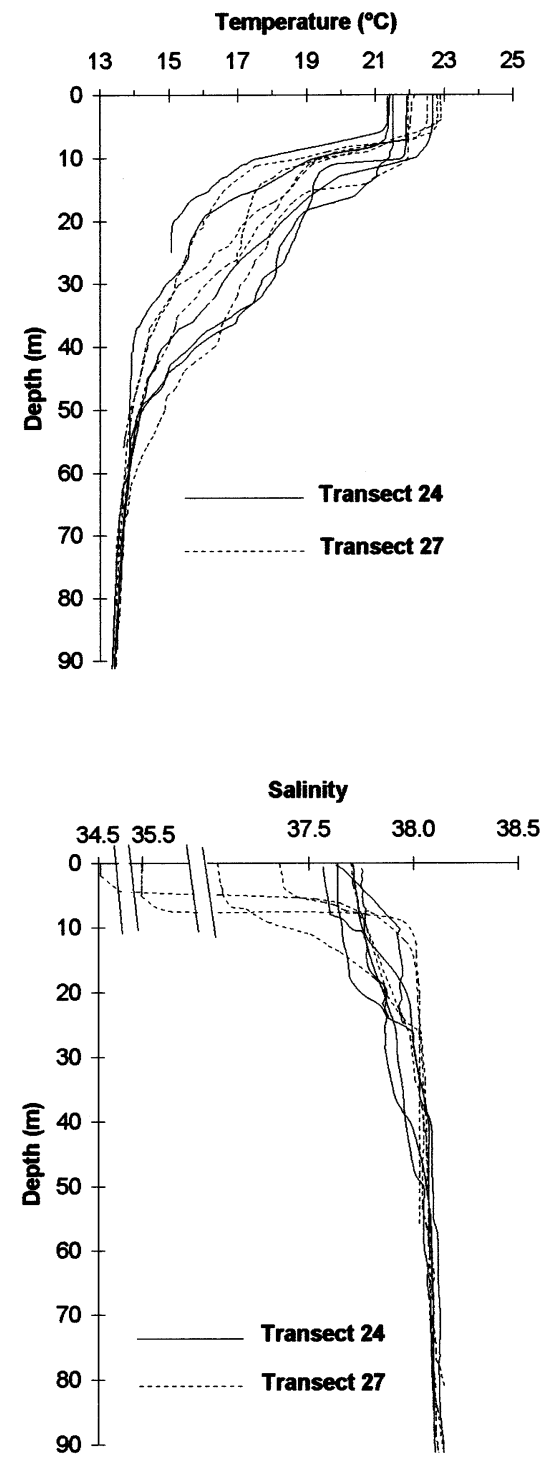

Figure 2. Temperature and salinity profiles from the bottom of the water column to the surface in areas 1 and 2 during PELMED 95 and along transects 24 and 27 during PELMED 96.

armata were dried at $50{ }^{\circ} \mathrm{C}$ for $72 \mathrm{~h}$. As suggested by James [23], a power regression of dry weight versus total length (except furca) was calculated and used to estimate the weight of other copepod species. Sets of fish larvae and crustacean larvae of each group were dried at $50{ }^{\circ} \mathrm{C}$ for $72 \mathrm{~h}$; their mean values were used in index calculations. For rare prey items, we used the equations given by James [23].

\section{RESULTS}

\subsection{Hydrological features}

In both areas (PM 95) and along both transects (PM 96), the water column showed strong thermal stratification (figure 2). The thermocline was situated between $10-20 \mathrm{~m}$ depth in area 1 and between $8-15 \mathrm{~m}$ 
depth in area 2. Along transect 24, the superficial thermocline was located between $8-20 \mathrm{~m}$. A second deeper thermocline (30-60 $\mathrm{m}$ depth) was observed at three stations (C, D, E). Along transect 27, the second thermocline was situated just below the upper one.

The water column was more stratified in salinity in areas 1 and 2 during PM 95 than along transects 24 and 27 during PM 96 (figure 2). In both areas and along transect 27, the halocline was located at a similar depth to the thermocline. Along transect 24, the water column was homogeneous in salinity.

During PELMED 95, the last profile in each area was performed after a 3-day gale force wind (Mistral and Tramontane at 30 knots), which induced water mixing. Salinity was homogeneous and the thermocline sank to depths of $35 \mathrm{~m}$ (area 1) and $25 \mathrm{~m}$ (area 2).

\subsection{Zooplankton}

Zooplankton biomass was higher above the thermocline than below (mean values round $20 \mathrm{mg} \cdot \mathrm{m}^{-3}$ and around $10 \mathrm{mg} \cdot \mathrm{m}^{-3}$ respectively) during both PM 95 and PM 96 (table II). Zooplankton composition also varied above and below the thermocline (tables III, $I V$ ). Above the thermocline cladocerans (Penilia avirostris) and doliols swarmed and copepods made up less than $45 \%$ of the total zooplankton in all areas and transects studied. Below the thermocline, copepods were dominant, with mean values ranging between $48 \%$ and $80 \%$.

The most abundant copepods above and below the thermocline during PM 95, in decreasing order of importance were Clausocalanus spp., Paracalanus parvus, Temora stylifera, Oncaea spp., Centropages typicus, Corycaeus spp. and Oithona plumifera. The same species dominated during PM 96, although the order of importance was slightly different.

Table II. PELMED 95 and PELMED 96. Zooplankton dry weight $\left(\mathrm{mg} \cdot \mathrm{m}^{-3}\right)$ with $200 \mu \mathrm{m}$ net and $80 \mu \mathrm{m}$ net.

\begin{tabular}{|c|c|c|c|c|c|}
\hline \multirow[t]{2}{*}{ Cruise } & \multirow[t]{2}{*}{ Zone } & \multirow[t]{2}{*}{ Station No. } & \multicolumn{2}{|c|}{$200 \mu \mathrm{m}$ net } & \multirow[t]{2}{*}{$80 \mu \mathrm{m}$ net } \\
\hline & & & $\mathrm{a}^{\mathrm{a}}$ & $b^{a}$ & \\
\hline \multirow[t]{13}{*}{ PELMED 95} & \multirow[t]{9}{*}{ Area 1} & $14^{\mathrm{b}}$ & 20.8 & - & - \\
\hline & & 15 & 39.7 & 24.4 & - \\
\hline & & 16 & 08.2 & 02.7 & - \\
\hline & & 17 & 26.6 & 06.2 & - \\
\hline & & 23 & 06.4 & 08.4 & - \\
\hline & & $24^{\mathrm{b}}$ & 18.2 & - & - \\
\hline & & $25^{\mathrm{b}}$ & 06.8 & - & - \\
\hline & & 30 & 27.6 & 17.3 & - \\
\hline & & 18 & 31.4 & 11.1 & - \\
\hline & \multirow{4}{*}{ Area 2} & $19^{\mathrm{b}}$ & 37.3 & - & - \\
\hline & & 20 & 22.8 & 19.6 & - \\
\hline & & 21 & 18.2 & 13.7 & - \\
\hline & & $27^{\mathrm{b}}$ & 27.5 & - & - \\
\hline \multirow[t]{10}{*}{ PELMED 96} & \multirow[t]{5}{*}{ Transect 24} & $\mathrm{~A}^{\mathrm{c}}$ & 15.3 & - & 19.9 \\
\hline & & $\mathrm{B}$ & 17.6 & 11.3 & 15.6 \\
\hline & & $\mathrm{C}$ & 22.6 & 09.4 & 15.2 \\
\hline & & $\mathrm{D}$ & 17.4 & 08.3 & 09.7 \\
\hline & & $\mathrm{E}$ & 11.0 & 00.9 & 08.7 \\
\hline & \multirow[t]{5}{*}{ Transect 27} & $\mathrm{~F}^{\mathrm{c}}$ & 15.6 & - & 10.6 \\
\hline & & G & 17.8 & 15.2 & 21.8 \\
\hline & & $\mathrm{H}$ & 11.7 & 09.6 & 09.5 \\
\hline & & I & 16.5 & 06.9 & 07.8 \\
\hline & & $\mathrm{J}$ & 30.3 & 05.0 & 07.1 \\
\hline
\end{tabular}

\footnotetext{
a a: Above thermocline; b: below thermocline.

${ }^{b}$ Malfunction of the opening-closing mechanism.

${ }^{\mathrm{c}}$ Plankton tows from the bottom to the surface.
} 
Table III. PELMED 95. Zooplankton composition and density (ind. $\mathrm{m}^{-3}$ ) above (a) and below (b) the thermocline in areas 1 and 2 .

\begin{tabular}{|c|c|c|c|c|c|c|c|c|c|c|c|c|c|c|c|c|c|c|c|c|c|c|c|c|c|c|}
\hline \multirow{3}{*}{$\begin{array}{l}\text { Area } \\
\text { Sampling stations } \\
\text { Water column }\end{array}$} & \multicolumn{16}{|l|}{1} & \multicolumn{10}{|l|}{2} \\
\hline & \multicolumn{2}{|l|}{14} & \multicolumn{2}{|l|}{15} & \multicolumn{2}{|l|}{16} & \multicolumn{2}{|l|}{17} & \multicolumn{2}{|l|}{23} & \multicolumn{2}{|l|}{24} & \multicolumn{2}{|l|}{25} & \multicolumn{2}{|l|}{30} & \multicolumn{2}{|l|}{18} & 19 & & 20 & & 21 & & 27 & \\
\hline & a & $\mathrm{b}^{\mathrm{a}}$ & a & $\mathrm{b}$ & a & b & a & $\mathrm{b}$ & a & $\mathrm{b}$ & a & $\mathrm{b}^{\mathrm{a}}$ & a & $\mathrm{b}^{\mathrm{a}}$ & a & $\mathrm{b}$ & a & $\mathrm{b}$ & $\mathrm{a}$ & $\mathrm{b}^{\mathrm{a}}$ & a & $\mathrm{b}$ & $\mathrm{a}$ & $\mathrm{b}$ & $\mathrm{a}$ & $\mathrm{b}^{\mathrm{a}}$ \\
\hline Copepoda & & & & & & & & & & & & & & & & & & & & & & & & & & \\
\hline Acartia clausi & 21 & & 10 & 6 & 9 & 2 & 3 & - & 1 & 6 & 3 & & - & & 7 & 20 & 7 & - & 29 & & 65 & 9 & 36 & 18 & - & \\
\hline Candacia armata & - & & - & 8 & 4 & 3 & - & - & - & 3 & 8 & & 1 & & 2 & 4 & - & - & 13 & & - & 4 & 5 & 5 & - & \\
\hline Centropages typicus & 88 & & 26 & 101 & 7 & 26 & 10 & 1 & 4 & 13 & 11 & & 1 & & 2 & 5 & 42 & 34 & 65 & & 17 & 14 & 18 & 15 & 7 & \\
\hline Clausocalanidae and Paracalanidae & 190 & & 228 & 158 & 65 & 92 & 202 & 24 & 29 & 92 & 107 & & 152 & & 226 & 73 & 218 & 81 & 114 & & 100 & 196 & 65 & 93 & 637 & \\
\hline Euchaeta marina & 7 & & - & 6 & 4 & - & - & - & - & - & - & & - & & - & - & - & - & - & & - & - & - & - & - & \\
\hline Pleuromamma gracilis & 2 & & - & 8 & - & 1 & 7 & - & - & 5 & - & & 5 & & - & - & - & 3 & - & & - & - & - & 2 & - & \\
\hline Pontella mediterranea & - & & - & - & - & - & - & - & - & - & 2 & & - & & - & - & 3 & - & - & & - & - & 2 & - & - & \\
\hline Temora stylifera & 172 & & 72 & 43 & 22 & 6 & 215 & - & 58 & 13 & 31 & & 2 & & 42 & 18 & 130 & 23 & 163 & & 87 & 13 & 68 & 29 & 252 & \\
\hline Clytemnestra rostrata & - & & - & - & - & - & - & - & - & - & - & & - & & - & - & - & - & - & & - & 1 & - & - & - & \\
\hline Euterpina acutifrons & - & & - & - & - & - & - & - & - & - & - & & - & & - & - & - & - & - & & - & - & - & - & - & \\
\hline Microsetella rosea & - & & - & - & - & - & - & - & - & - & - & & - & & - & - & - & - & - & & - & - & - & - & - & \\
\hline Oncaea spp. & 16 & & - & 11 & 46 & 28 & 7 & 4 & 6 & 6 & 3 & & 6 & & 3 & 1 & 13 & 3 & 65 & & 100 & 31 & 8 & 17 & 59 & \\
\hline Corycaeus spp. & 20 & & 20 & 13 & 9 & 9 & 7 & 4 & 4 & 1 & 8 & & 6 & & 10 & 2 & - & 5 & 29 & & 17 & 10 & 8 & 12 & 48 & \\
\hline Oithona plumifera & 5 & & 10 & 18 & 4 & 22 & 7 & - & 2 & 19 & 5 & & 1 & & 2 & 15 & 10 & 14 & 49 & & 9 & 21 & - & 26 & 11 & \\
\hline Sapphirina spp. & - & & - & - & - & - & - & - & - & - & - & & - & & - & - & - & - & - & & - & - & - & - & - & \\
\hline Unidentified Copepoda & - & & - & - & - & - & - & - & - & - & - & & - & & - & - & - & - & - & & - & - & - & - & - & \\
\hline Copepodite stages & - & & - & - & - & - & - & - & - & - & - & & - & & - & - & - & - & - & & - & - & - & - & - & \\
\hline Cladocera & & & & & & & & & & & & & & & & & & & & & & & & & & \\
\hline Penilia avirostris & 881 & & 836 & 225 & 282 & 58 & 468 & - & 152 & 9 & 174 & & - & & 291 & 78 & 1109 & 100 & 1473 & & 898 & 40 & 345 & 207 & 512 & \\
\hline Evadne spinifera & 341 & & 272 & 233 & 102 & 33 & 109 & - & 15 & 6 & 46 & & 5 & & 9 & 2 & 62 & 25 & 186 & & 269 & 30 & 194 & 39 & 463 & \\
\hline Podon polyphemoides & 10 & & 5 & 5 & - & 4 & 2 & - & 2 & 4 & 4 & & - & & 1 & - & - & 9 & 3 & & 9 & 3 & 13 & 1 & 2 & \\
\hline Crustacea & & & & & & & & & & & & & & & & & & & & & & & & & & \\
\hline Unidentified Decapoda Larvae & - & & - & - & - & - & 3 & - & 2 & - & - & & 1 & & 1 & - & - & - & - & & 4 & - & - & - & - & \\
\hline Unidentified Euphausiacea Larvae & 13 & & - & 4 & 4 & 4 & 10 & - & 1 & 2 & 2 & & 1 & & 3 & 11 & 10 & 4 & 13 & & - & 7 & 2 & 2 & 4 & \\
\hline Unidentified Mysidacea Larvae & - & & - & - & - & - & - & - & - & - & - & & - & & - & - & - & - & - & & - & - & - & - & - & \\
\hline Amphipoda (juveniles) & - & & - & - & - & - & - & - & - & - & - & & - & & - & - & - & - & - & & - & - & - & - & - & \\
\hline Miscellaneaous & & & & & & & & & & & & & & & & & & & & & & & & & & \\
\hline Doliolidae & 772 & & 745 & 45 & 1637 & 96 & 618 & - & 156 & - & 320 & & 3 & & 226 & 115 & 1610 & 23 & 533 & & 867 & 20 & 89 & 265 & 644 & \\
\hline Chaetognata & 11 & & 16 & 1 & 7 & - & 3 & - & 1 & - & 10 & & - & & 3 & 1 & 7 & 1 & 29 & & 22 & 6 & 8 & 2 & 4 & \\
\hline Appendicularia (Oikopleura sp.) & - & & - & 1 & 2 & 1 & 3 & - & 5 & 10 & 39 & & 58 & & 18 & 29 & 49 & 12 & 7 & & 56 & 39 & - & 14 & 22 & \\
\hline Tintinnididae & 37 & & 62 & 4 & 11 & 7 & 13 & 2 & - & 2 & 3 & & - & & - & - & 13 & 3 & 16 & & 4 & - & 7 & 5 & 4 & \\
\hline Siphonophora & 2 & & 7 & - & - & - & - & - & - & - & - & & - & & - & - & - & - & - & & - & - & - & - & - & \\
\hline Ostracoda & 3 & & - & 1 & 2 & 1 & - & 3 & 1 & - & - & & 7 & & - & - & - & 3 & - & & - & 2 & - & - & - & \\
\hline Mollusca & - & & 7 & 3 & - & 1 & - & - & - & - & - & & - & & 1 & - & - & 1 & - & & 4 & - & - & - & - & \\
\hline Polycheta & 2 & & - & - & - & 1 & - & - & - & - & - & & - & & - & - & - & - & - & & - & 2 & - & - & - & \\
\hline Clupeiod fish larvae & - & & - & - & - & - & - & - & - & - & - & & - & & - & - & - & - & - & & - & - & - & - & - & \\
\hline Unidentified fish larvae & 2 & & 3 & - & - & - & - & - & - & - & - & & - & & - & - & - & 1 & 3 & & - & 1 & - & 3 & - & \\
\hline Anchovy eggs & 8 & & 3 & - & 4 & 1 & 7 & - & - & - & - & & - & & 2 & - & 3 & - & - & & 9 & - & 2 & 6 & - & \\
\hline Unidentified fish eggs & 15 & & 3 & - & - & - & 7 & - & - & - & - & & 2 & & 2 & - & - & 1 & - & & - & - & - & - & 11 & \\
\hline Total & 2618 & & 2328 & 892 & 2220 & 396 & 1698 & 38 & 437 & 191 & 777 & & 249 & & 851 & 375 & 3285 & 344 & 2790 & & 2537 & 447 & 868 & 759 & 2678 & \\
\hline Copepoda (\%) & 20 & & 16 & 42 & 8 & 48 & 27 & 87 & 24 & 83 & 23 & & 70 & & 35 & 37 & 13 & 47 & 19 & & 16 & 67 & 24 & 29 & 38 & \\
\hline Cladocera (\%) & 47 & & 48 & 52 & 17 & 24 & 34 & - & 39 & 10 & 29 & & 2 & & 35 & 21 & 36 & 39 & 60 & & 46 & 16 & 64 & 32 & 36 & \\
\hline Doliolidae (\%) & 30 & & 32 & 5 & 74 & 24 & 36 & - & 36 & - & 41 & & 1 & & 27 & 31 & 49 & 7 & 19 & & 34 & 4 & 10 & 35 & 24 & \\
\hline
\end{tabular}

${ }^{a}$ Malfunction of the opening-closing mechanism. 
Table IV. PELMED 96. Zooplankton composition and density (ind. $\cdot \mathrm{m}^{-3}$ ) with $200 \mu \mathrm{m}$ net and $80 \mu \mathrm{m}$ net along transects 24 and 27.

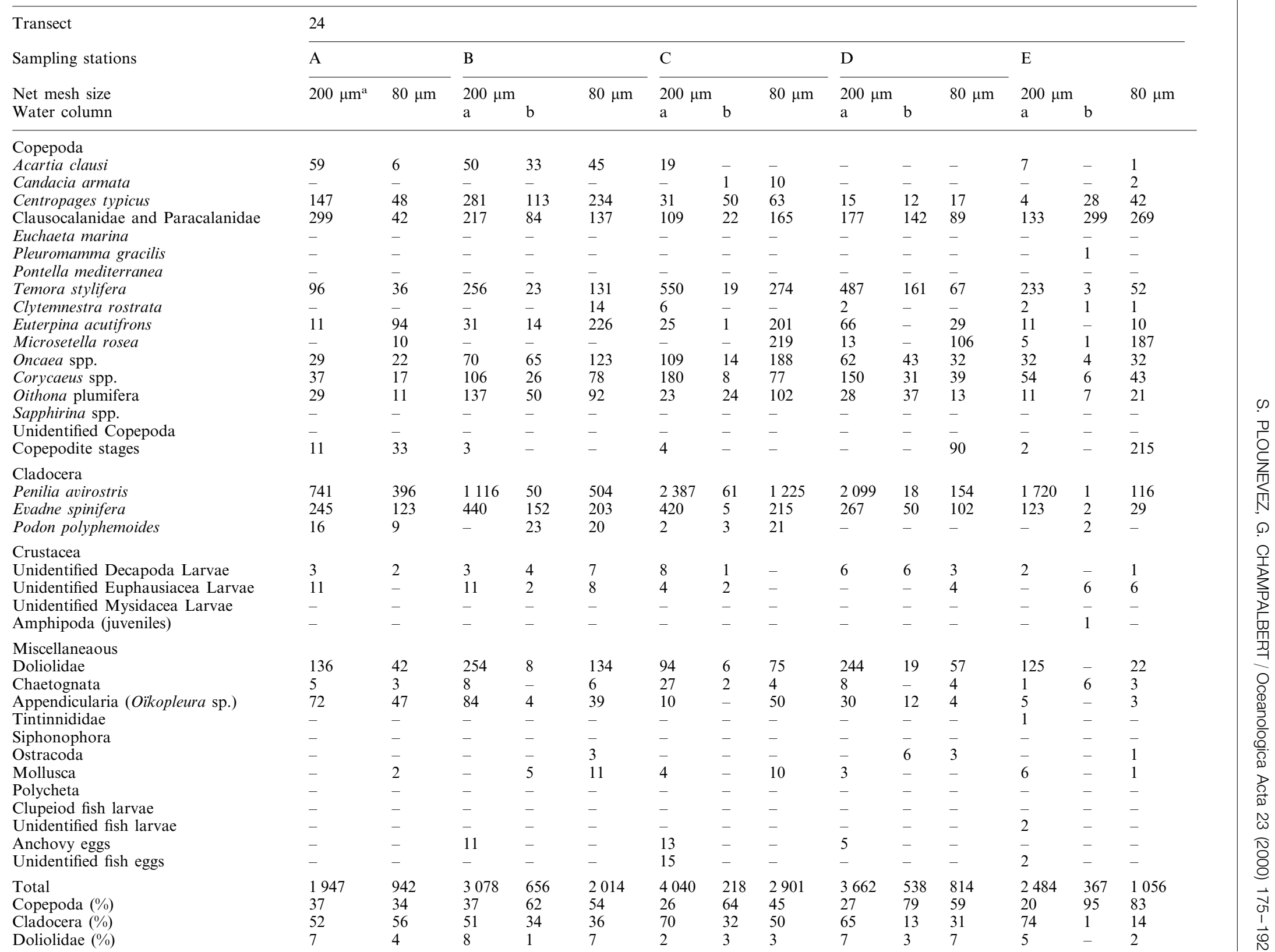


Table IV. (Continued)

\begin{tabular}{|c|c|c|c|c|c|c|c|c|c|c|c|c|c|c|}
\hline Transect & 27 & & & & & & & & & & & & & \\
\hline Sampling stations & $\mathrm{F}$ & & G & & & $\mathrm{H}$ & & & I & & & $\mathrm{J}$ & & \\
\hline $\begin{array}{l}\text { Net mesh size } \\
\text { Water column }\end{array}$ & $200 \mu \mathrm{m}^{\mathrm{a}}$ & $80 \mu \mathrm{m}$ & $\begin{array}{l}200 \mu \mathrm{m} \\
\mathrm{a}\end{array}$ & $\mathrm{b}$ & $80 \mu \mathrm{m}$ & $\begin{array}{l}200 \mu \mathrm{m} \\
\mathrm{a}\end{array}$ & $\mathrm{b}$ & $80 \mu \mathrm{m}$ & $\begin{array}{l}200 \mu \mathrm{m} \\
\mathrm{a}\end{array}$ & b & $80 \mu \mathrm{m}$ & $\begin{array}{l}200 \mu \mathrm{m} \\
\mathrm{a}\end{array}$ & $\mathrm{b}$ & $80 \mu \mathrm{m}$ \\
\hline $\begin{array}{l}\text { Copepoda } \\
\text { Acartia clausi } \\
\text { Candacia armata } \\
\text { Centropages typicus } \\
\text { Clausocalanidae and Paracalanidae } \\
\text { Euchaeta marina } \\
\text { Pleuromamma gracilis } \\
\text { Pontella mediterranea } \\
\text { Temora stylifera } \\
\text { Clytemnestra rostrata } \\
\text { Euterpina acutifrons } \\
\text { Microsetella rosea } \\
\text { Oncaea spp. } \\
\text { Corycaeus spp. } \\
\text { Oithona plumifera } \\
\text { Sapphirina spp. } \\
\text { Unidentified Copepoda } \\
\text { Copepodite stages }\end{array}$ & $\begin{array}{l}47 \\
- \\
110 \\
336 \\
- \\
31 \\
- \\
27 \\
- \\
20 \\
1 \\
64 \\
51 \\
13 \\
- \\
- \\
29\end{array}$ & $\begin{array}{l}13 \\
- \\
109 \\
279 \\
- \\
- \\
- \\
29 \\
- \\
17 \\
30 \\
49 \\
30 \\
9 \\
- \\
- \\
117\end{array}$ & $\begin{array}{l}43 \\
- \\
113 \\
298 \\
- \\
- \\
- \\
86 \\
- \\
64 \\
- \\
51 \\
61 \\
26 \\
- \\
- \\
7\end{array}$ & $\begin{array}{l}32 \\
- \\
225 \\
175 \\
- \\
- \\
- \\
34 \\
- \\
10 \\
1 \\
46 \\
63 \\
70 \\
- \\
2 \\
-\end{array}$ & $\begin{array}{l}48 \\
5 \\
77 \\
235 \\
- \\
- \\
- \\
51 \\
- \\
227 \\
71 \\
144 \\
32 \\
85 \\
- \\
- \\
381\end{array}$ & $\begin{array}{l}5 \\
- \\
10 \\
99 \\
- \\
- \\
- \\
255 \\
-7 \\
2 \\
11 \\
42 \\
12 \\
- \\
- \\
-\end{array}$ & $\begin{array}{l}3 \\
3 \\
46 \\
68 \\
4 \\
5 \\
- \\
23 \\
1 \\
8 \\
1 \\
37 \\
22 \\
68 \\
- \\
2 \\
80\end{array}$ & $\begin{array}{l}2 \\
1 \\
32 \\
90 \\
- \\
1 \\
- \\
52 \\
1 \\
15 \\
48 \\
18 \\
13 \\
29 \\
- \\
1 \\
17\end{array}$ & $\begin{array}{l}13 \\
- \\
49 \\
77 \\
- \\
- \\
- \\
268 \\
1 \\
27 \\
1 \\
12 \\
81 \\
14 \\
1 \\
- \\
5\end{array}$ & $\begin{array}{l}3 \\
1 \\
55 \\
80 \\
1 \\
- \\
- \\
55 \\
- \\
9 \\
3 \\
19 \\
29 \\
26 \\
- \\
- \\
15\end{array}$ & $\begin{array}{l}5 \\
- \\
77 \\
69 \\
1 \\
- \\
- \\
91 \\
1 \\
26 \\
30 \\
28 \\
40 \\
30 \\
1 \\
2 \\
27\end{array}$ & $\begin{array}{l}22 \\
3 \\
204 \\
224 \\
3 \\
- \\
- \\
338 \\
1 \\
28 \\
3 \\
22 \\
80 \\
20 \\
1 \\
- \\
-\end{array}$ & $\begin{array}{l}2 \\
- \\
22 \\
17 \\
1 \\
- \\
- \\
16 \\
- \\
1 \\
- \\
9 \\
7 \\
5 \\
- \\
- \\
1\end{array}$ & $\begin{array}{l}- \\
2 \\
43 \\
27 \\
- \\
- \\
- \\
56 \\
1 \\
27 \\
15 \\
16 \\
15 \\
12 \\
- \\
4 \\
31\end{array}$ \\
\hline $\begin{array}{l}\text { Cladocera } \\
\text { Penilia avirostris } \\
\text { Evadne spinifera } \\
\text { Podon polyphemoides }\end{array}$ & $\begin{array}{l}134 \\
58 \\
2\end{array}$ & $\begin{array}{l}85 \\
29 \\
4\end{array}$ & $\begin{array}{l}728 \\
219 \\
9\end{array}$ & $\begin{array}{l}497 \\
22 \\
31\end{array}$ & $\begin{array}{l}728 \\
80 \\
11\end{array}$ & $\begin{array}{l}487 \\
47 \\
-\end{array}$ & $\begin{array}{l}234 \\
6 \\
3\end{array}$ & $\begin{array}{l}200 \\
11 \\
1\end{array}$ & $\begin{array}{l}1654 \\
74 \\
-\end{array}$ & $\begin{array}{l}87 \\
5 \\
1\end{array}$ & $\begin{array}{l}238 \\
19 \\
2\end{array}$ & $\begin{array}{l}310 \\
60 \\
2\end{array}$ & $\begin{array}{l}9 \\
1 \\
1\end{array}$ & $\begin{array}{l}63 \\
1 \\
1\end{array}$ \\
\hline $\begin{array}{l}\text { Crustacea } \\
\text { Unidentified Decapoda Larvae } \\
\text { Unidentified Euphausiacea Larvae } \\
\text { Unidentified Mysidacea Larvae } \\
\text { Amphipoda (juveniles) }\end{array}$ & $\begin{array}{l}1 \\
6 \\
- \\
-\end{array}$ & $\begin{array}{l}- \\
12 \\
- \\
-\end{array}$ & $\begin{array}{l}- \\
3 \\
1 \\
-\end{array}$ & $\begin{array}{l}- \\
3 \\
- \\
-\end{array}$ & $\begin{array}{l}- \\
8 \\
- \\
-\end{array}$ & $\begin{array}{l}3 \\
2 \\
- \\
-\end{array}$ & $\begin{array}{l}2 \\
5 \\
7 \\
-\end{array}$ & $\begin{array}{l}1 \\
5 \\
6 \\
-\end{array}$ & $\begin{array}{l}- \\
1 \\
- \\
-\end{array}$ & $\begin{array}{l}- \\
3 \\
7 \\
-\end{array}$ & $\begin{array}{l}1 \\
3 \\
7 \\
-\end{array}$ & $\begin{array}{l}7 \\
8 \\
- \\
-\end{array}$ & $\begin{array}{l}- \\
- \\
1 \\
-\end{array}$ & $\begin{array}{l}- \\
3 \\
1 \\
-\end{array}$ \\
\hline $\begin{array}{l}\text { Miscellaneaous } \\
\text { Doliolidae } \\
\text { Chaetognata } \\
\text { Appendicularia (Oikopleura sp.) } \\
\text { Tintinnididae } \\
\text { Siphonophora } \\
\text { Ostracoda } \\
\text { Mollusca } \\
\text { Polycheta } \\
\text { Clupeiod fish larvae } \\
\text { Unidentified fish larvae } \\
\text { Anchovy eggs } \\
\text { Unidentified fish eggs }\end{array}$ & $\begin{array}{l}16 \\
9 \\
78 \\
- \\
- \\
- \\
3 \\
- \\
- \\
4 \\
- \\
-\end{array}$ & $\begin{array}{l}7 \\
12 \\
71 \\
- \\
- \\
- \\
- \\
- \\
- \\
- \\
- \\
-\end{array}$ & $\begin{array}{l}54 \\
19 \\
11 \\
- \\
- \\
- \\
- \\
- \\
- \\
- \\
6 \\
5\end{array}$ & $\begin{array}{l}36 \\
13 \\
23 \\
- \\
- \\
1 \\
- \\
- \\
3 \\
- \\
1 \\
-\end{array}$ & $\begin{array}{l}80 \\
16 \\
67 \\
8 \\
- \\
- \\
5 \\
- \\
- \\
- \\
5 \\
-\end{array}$ & $\begin{array}{l}215 \\
- \\
6 \\
- \\
- \\
2 \\
- \\
- \\
- \\
- \\
11 \\
-\end{array}$ & $\begin{array}{l}37 \\
12 \\
19 \\
- \\
- \\
3 \\
1 \\
- \\
- \\
- \\
- \\
-\end{array}$ & $\begin{array}{l}107 \\
11 \\
37 \\
- \\
- \\
2 \\
- \\
1 \\
- \\
- \\
1 \\
-\end{array}$ & $\begin{array}{l}242 \\
5 \\
5 \\
- \\
- \\
- \\
- \\
- \\
- \\
- \\
3 \\
-\end{array}$ & $\begin{array}{l}47 \\
4 \\
14 \\
- \\
- \\
3 \\
- \\
2 \\
- \\
- \\
- \\
-\end{array}$ & $\begin{array}{l}55 \\
9 \\
25 \\
- \\
- \\
1 \\
- \\
- \\
- \\
- \\
2 \\
-\end{array}$ & $\begin{array}{l}356 \\
20 \\
13 \\
- \\
- \\
1 \\
3 \\
- \\
3 \\
- \\
12 \\
-\end{array}$ & $\begin{array}{l}14 \\
2 \\
1 \\
- \\
- \\
1 \\
- \\
- \\
- \\
- \\
- \\
-\end{array}$ & $\begin{array}{l}70 \\
9 \\
13 \\
- \\
- \\
1 \\
- \\
- \\
- \\
- \\
1 \\
-\end{array}$ \\
\hline $\begin{array}{l}\text { Total } \\
\text { Copepoda }(\%) \\
\text { Cladocera }(\%) \\
\text { Doliolidae }(\%)\end{array}$ & $\begin{array}{l}1040 \\
70 \\
19 \\
2\end{array}$ & $\begin{array}{l}903 \\
76 \\
13 \\
1\end{array}$ & $\begin{array}{l}1804 \\
42 \\
53 \\
3\end{array}$ & $\begin{array}{l}1290 \\
51 \\
43 \\
3\end{array}$ & $\begin{array}{l}2365 \\
57 \\
35 \\
3\end{array}$ & $\begin{array}{l}1215 \\
36 \\
44 \\
18\end{array}$ & $\begin{array}{l}698 \\
53 \\
35 \\
5\end{array}$ & $\begin{array}{l}705 \\
46 \\
30 \\
15\end{array}$ & $\begin{array}{l}2532 \\
22 \\
68 \\
10\end{array}$ & $\begin{array}{l}470 \\
63 \\
20 \\
10\end{array}$ & $\begin{array}{l}788 \\
54 \\
33 \\
7\end{array}$ & $\begin{array}{l}1745 \\
54 \\
21 \\
20\end{array}$ & $\begin{array}{l}111 \\
71 \\
10 \\
12\end{array}$ & $\begin{array}{l}414 \\
60 \\
16 \\
17\end{array}$ \\
\hline
\end{tabular}

a Plankton tows from the bottom to the surface. 


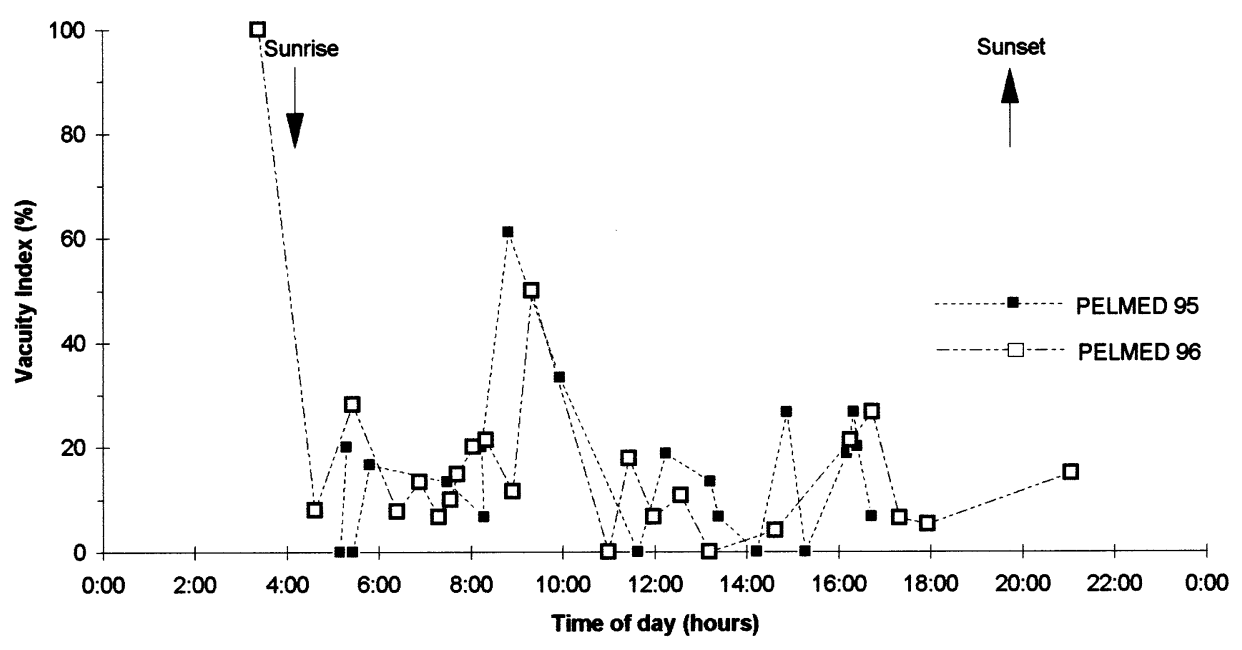

Figure 3. PELMED 95 and PELMED 96. Vacuity index of anchovy stomachs versus time of day (U.T.).

Dominant groups were similar in samples collected with either the $80 \mu \mathrm{m}$ net or with the $200 \mu \mathrm{m}$ net above the thermocline during PM 96 (table IV). Nevertheless, Microsetella rosea, a copepod absent from PM 95 collections, was very rare in plankton sampled with a $200 \mu \mathrm{m}$ net during PM 96 but abundant in plankton sampled with a $80 \mu \mathrm{m}$ net.

\subsection{Feeding activity and consumption during the day by adult anchovy}

Adult anchovy live in shoals under the thermocline during the daytime and are scattered above the thermocline during the night; the diel vertical migrations occur at sunset and sunrise for a brief time interval (20-30 min, B. Liorzou, pers. comm.).

The vacuity index and the fullness index of anchovy showed that the fish had a continuous feeding activity pattern during the day and the early night (figures 3, 4). Late at night $(4 \mathrm{~h})$, anchovy stomachs were empty, which suggests that anchovy feeding activity is low during the night (figure 4).

Neither size nor sex had a significant effect on the fullness index of anchovies used for food consumption estimates. Using Elliott and Persson's model [14] we obtained:

$\sum_{5: 40}^{16: 56} \mathrm{Ct}=33.7 \pm 17.3 \mathrm{~g}$ w.w. stomach content

$1000 \mathrm{~g}^{-1}$ w.w. body fish (PM 95) $\sum_{4: 37}^{17: 06} \mathrm{Ct}=38.7 \pm 23.1 \mathrm{~g}$ w.w. stomach content

$1000 \mathrm{~g}^{-1}$ w.w. body fish (PM 96)

Food consumption during the daytime, expressed as a percentage of anchovy wet weight was $3.4 \%$ and $3.9 \%$ during PM 95 and PM 96, respectively.

\subsection{Diet composition of adult anchovy}

Zooplankton made up the total bulk of the diet of all the anchovies in the two campaigns (table $V$ ). Copepods were the dominant prey items $\left(\overline{\sum \mathrm{I}_{\text {(copepods) }}}=\right.$ 0.86). The dominant prey copepods were Candacia armata, Centropages typicus, Microsetella rosea, Clausocalanidae-Paracalanidae and Temora stylifera, but their rankings were different according to the area or the transect (table $V$ ). The size of prey ranged between $0.8 \mathrm{~mm}$ (M. rosea) and $>4.0 \mathrm{~mm}$ (large crustacea).

The copepod Candacia armata had the highest mean I value, and also the smallest $\mathrm{CV}$, of the major prey items (table $V$ ). This relatively low $\mathrm{CV}$ indicates that C. armata was a major dietary component at all the stations, in contrast to some of the other prey which were locally important (e.g. ClausocalanidaeParacalanidae). 
The Costello graphical method showed that small copepods $(<1.1 \mathrm{~mm})$ such as Corycaeus spp., Oncaea spp. and Clausocalanidae-Paracalanidae were frequent ingested prey, $(55-80 \%)$ but constituted a low weight in anchovy stomachs $(<5 \%)$ regardless of anchovy size except in $11.5 \mathrm{~cm}$ anchovies from PM 96 (figures 5, 6). The occurrence of medium sized copepods $(1.5 \mathrm{~mm})$ such as Temora stylifera increased slightly with fish size (25 to $55 \%$ ) whereas weight variations (\%) were more irregular. Large prey items ( $>3 \mathrm{~mm}$ ) such as fish larvae, megalops and Euphausiacea larvae were not frequent $(<35 \%)$, but occasionally they made up $20-42 \%$ of the stomach content weight. Neither occurrence nor weight of fish larvae, Euphausiacea larvae and megalops increased with anchovy size. However, three copepods exhib- ited a clear pattern of variation: the occurrence and weight of the small-sized copepod Microsetella rosea decreased with increasing fish length. In contrast, the occurrence and weight of Centropages typicus (medium-large size, only found during PM96) and Candacia armata (large size) increased with increasing fish size.

\section{DISCUSSION}

\subsection{Hydrological conditions and zooplankton abundance in the Gulf of Lions}

During summer, the hydrology of the northwestern Mediterranean Sea is characterized by a strong
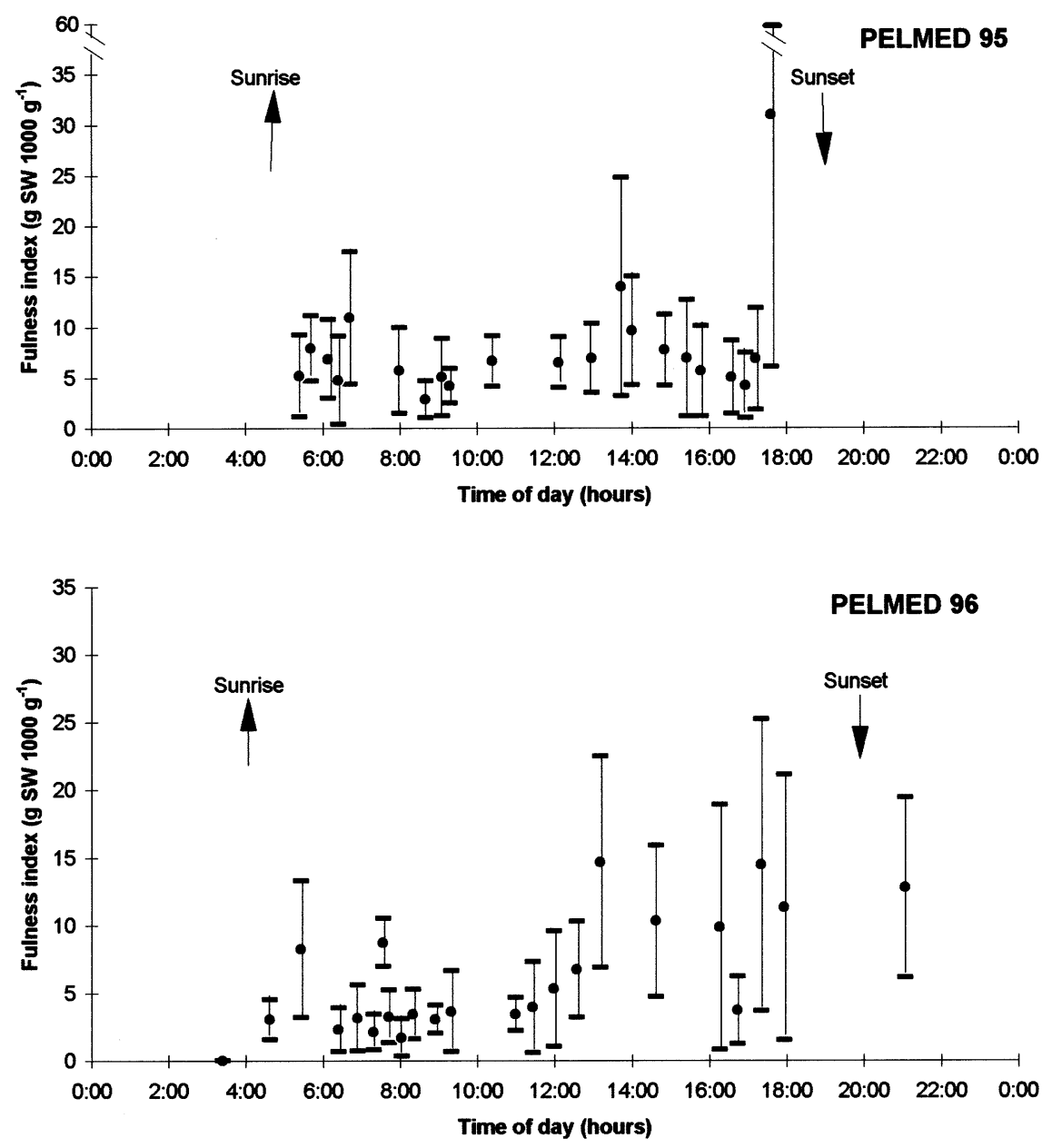

Figure 4. PELMED 95 and PELMED 96. Fullness index (mean \pm standard deviation) of anchovy stomachs versus time of day (U.T.). 

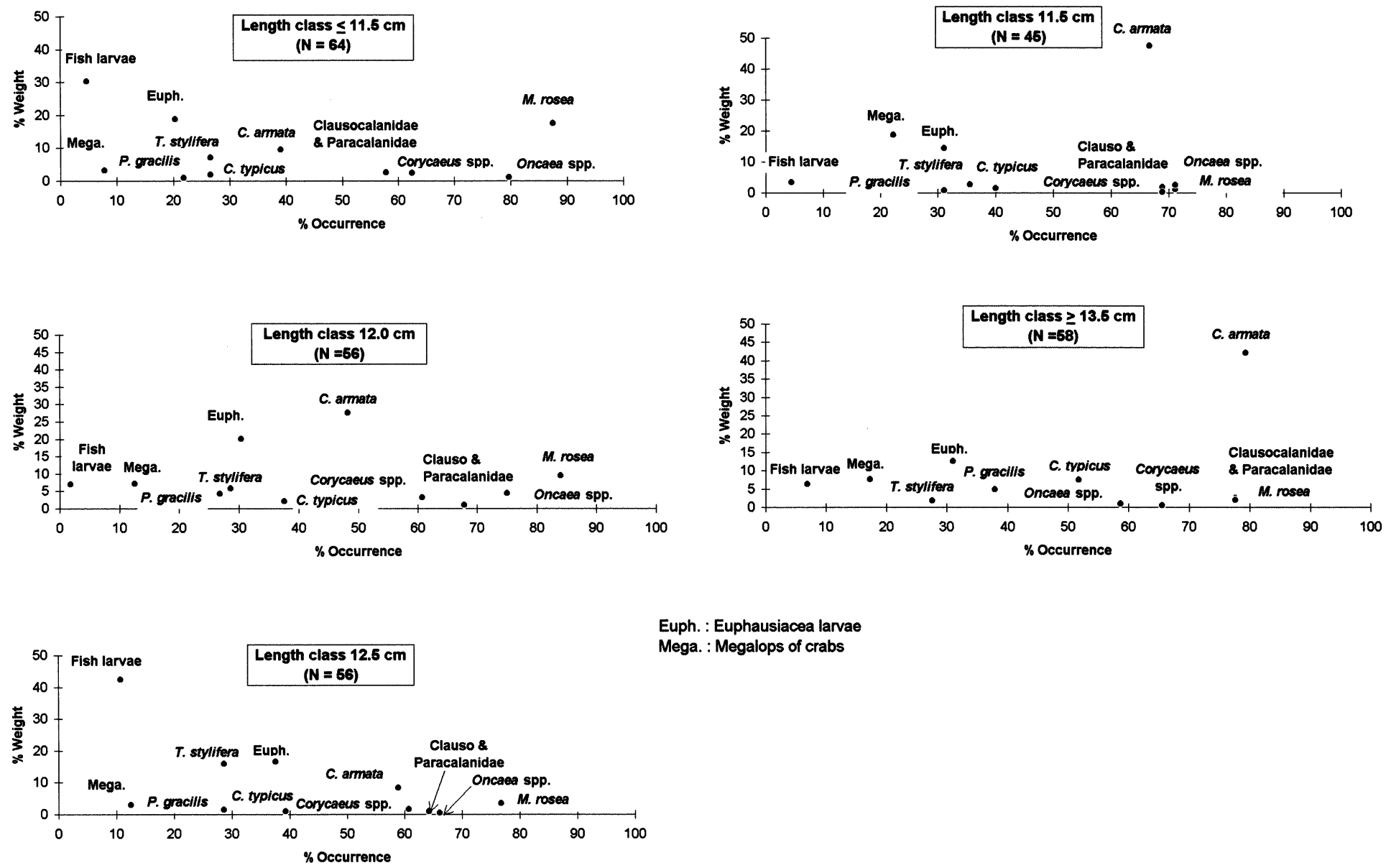

Euph. : Euphausiacea larvae

Mega. : Megalops of crabs

Figure 5. PELMED 95. Costello graphical representation of dominant prey items of five length classes of anchovies. 

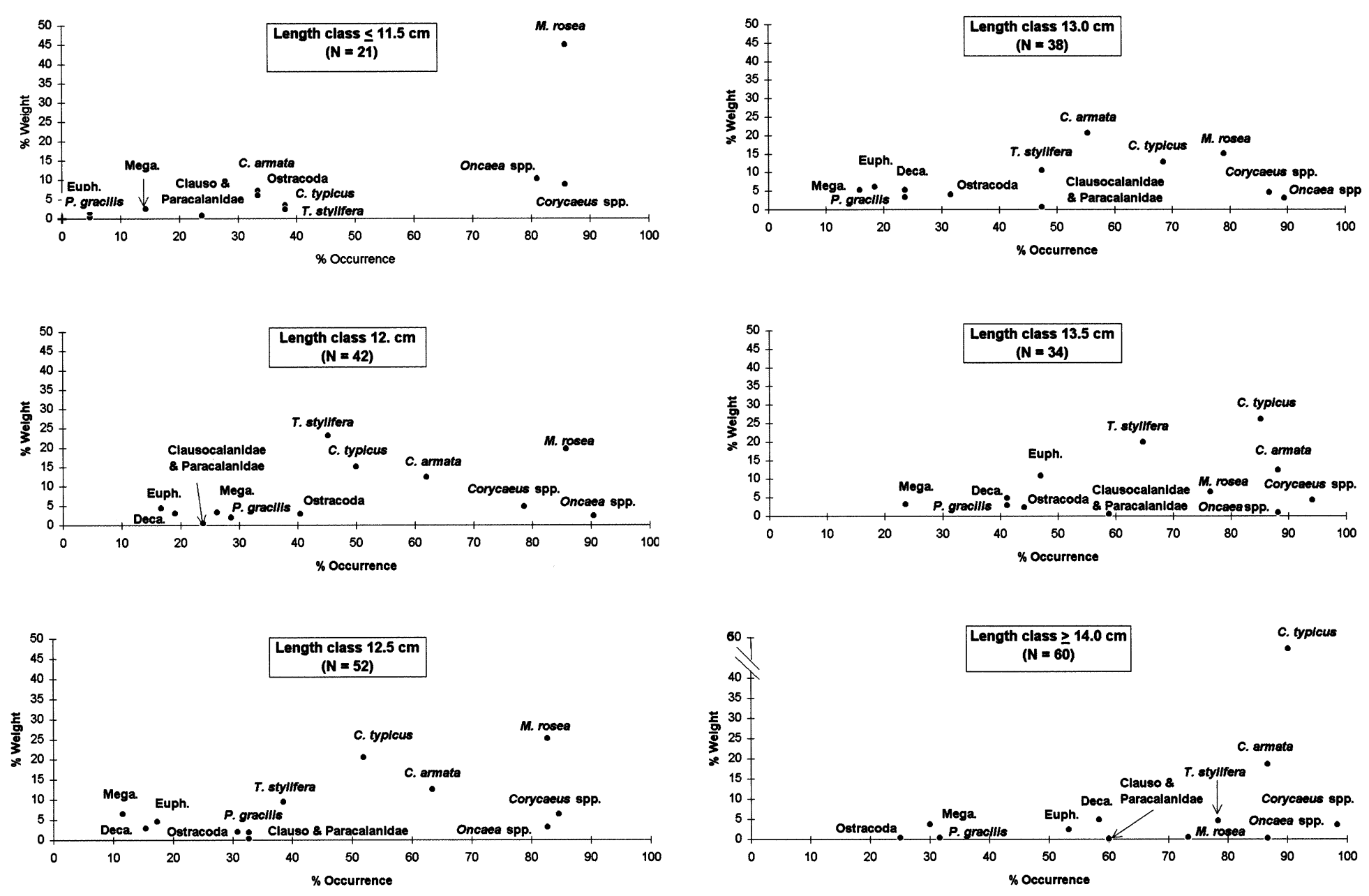

Deca. : Decapoda larvae ; Euph. : Euphausiacea larvae ; Mega. : Megalops of crabs

Figure 6. PELMED 96. Costello graphical representation of dominant prey items of six length classes of anchovies. 
Table V. PELMED 95 and PELMED 96. Index of preponderance of prey items in anchovy stomachs.

\begin{tabular}{|c|c|c|c|c|c|c|c|c|}
\hline \multirow{4}{*}{$\begin{array}{l}\text { Cruise } \\
\text { Leg } \\
\text { Area or transect } \\
\mathrm{N} \text { fish }\end{array}$} & \multicolumn{3}{|c|}{ PELMED 95} & \multirow{2}{*}{\multicolumn{2}{|c|}{$\begin{array}{l}\text { PELMED } 96 \\
2\end{array}$}} & \multirow[t]{4}{*}{ Mean } & \multirow[t]{4}{*}{ SD } & \multirow[t]{4}{*}{$\mathrm{CV}(\%)$} \\
\hline & \multirow[t]{2}{*}{1} & \multicolumn{2}{|l|}{2} & & & & & \\
\hline & & 1 & 2 & 24 & 27 & & & \\
\hline & 84 & 120 & 75 & 142 & 105 & & & \\
\hline \multicolumn{9}{|l|}{ Copepoda } \\
\hline Acartia clausi & 0.001 & - & - & - & - & - & - & - \\
\hline Candacia armata & 0.364 & 0.176 & 0.227 & 0.184 & 0.165 & 0.223 & 0.074 & 33 \\
\hline Centropages typicus & 0.101 & 0.028 & 0.024 & 0.655 & 0.080 & 0.178 & 0.240 & 135 \\
\hline Clausocalanidae and Paracalanidae & 0.074 & 0.423 & 0.064 & 0.001 & 0.004 & 0.113 & 0.158 & 139 \\
\hline Euchaeta marina & - & - & - & - & 0.007 & 0.001 & 0.003 & 198 \\
\hline Pleuromamma gracilis & 0.016 & 0.027 & 0.010 & - & 0.030 & 0.017 & 0.011 & 64 \\
\hline Temora stylifera & 0.067 & 0.001 & 0.260 & 0.039 & 0.180 & 0.109 & 0.096 & 88 \\
\hline Euterpina acutifrons & 0.006 & - & 0.001 & 0.003 & 0.001 & 0.002 & 0.002 & 106 \\
\hline Microsetella rosea & 0.071 & 0.130 & 0.064 & 0.010 & 0.306 & 0.116 & 0.102 & 88 \\
\hline Oncaea spp. & 0.041 & 0.067 & 0.029 & 0.007 & 0.032 & 0.035 & 0.019 & 55 \\
\hline Corycaeus spp. & 0.042 & 0.082 & 0.016 & 0.054 & 0.054 & 0.049 & 0.021 & 43 \\
\hline Oithona plumifera & - & 0.001 & - & - & - & - & - & - \\
\hline Sapphirina spp. & - & - & - & - & 0.001 & - & - & - \\
\hline Unidentified Copepoda & 0.025 & 0.014 & 0.003 & - & 0.012 & 0.011 & 0.009 & 81 \\
\hline \multicolumn{9}{|l|}{ Cladocera } \\
\hline Penilia avirostris & 0.002 & 0.001 & - & - & - & 0.001 & 0.001 & 128 \\
\hline Evadne spinifera & 0.001 & 0.001 & - & 0.001 & - & 0.001 & 0.000 & 71 \\
\hline \multicolumn{9}{|l|}{ Crustacea } \\
\hline Unidentified Decapoda Larvae & 0.007 & - & 0.006 & 0.025 & 0.020 & 0.012 & 0.009 & 79 \\
\hline Megalops of crabs & 0.030 & 0.002 & 0.024 & 0.005 & 0.041 & 0.020 & 0.015 & 74 \\
\hline Unidentified Euphausiacea Larvae & 0.084 & 0.028 & 0.129 & 0.013 & 0.032 & 0.057 & 0.043 & 75 \\
\hline Amphipoda (juveniles) & - & 0.001 & - & - & 0.001 & 0.000 & 0.001 & 122 \\
\hline \multicolumn{9}{|l|}{ Miscellaneous } \\
\hline Appendicularia (Ö̈kopleura sp.) & - & 0.002 & - & - & - & - & - & - \\
\hline Tintinnididae & 0.063 & 0.008 & 0.042 & - & - & 0.023 & 0.025 & 113 \\
\hline Ostracoda & 0.001 & 0.005 & 0.004 & 0.001 & 0.035 & 0.009 & 0.013 & 143 \\
\hline Mollusca & 0.002 & 0.001 & 0.001 & 0.001 & - & 0.001 & 0.000 & 45 \\
\hline Unidentified fish larvae & 0.002 & 0.001 & 0.093 & - & - & 0.019 & 0.037 & 191 \\
\hline
\end{tabular}

stratification of the water column and a seasonal thermocline between $10 \mathrm{~m}$ and $20 \mathrm{~m}[35,36]$. Water from the Rhone river spreads out into the superficial layer over the continental shelf $[36,43]$ and frequent (approximately ten per summer) northwesterly winds (Tramontane and Mistral) induce coastal upwellings and subsequent complex advective circulation [35]. In accordance with these common features, water was warmer and saltier above than below the thermocline during the PELMED cruises, and in late PELMED 95 we also observed extensive mixing of the water column after gale force winds.
Our data show that near the mouth of the Rhone river (area 1 and transect 27), plankton biomass was not different from that found in the central part of the Gulf of Lions near Cap d'Agde (area 2 and transect 24). These results suggest that nutrients from the Rhone river did not increase zooplankton biomass off the area directly influenced by the freshwater plume, and agree with Razouls and Kouwenberg's studies carried out in July in the same area [42].

In accordance with the water column stratification, the density and the specific composition of zooplankton were stratified. Mean biomass above the therm- 
cline was higher than below. With regard to the number of individuals per cubic metre, the differences between the two layers were striking, and above the thermocline, the most abundant species was Penilia avirostris. This cladoceran, which displays parthenogenetic reproduction, is known to swarm in the surface layer during summer [30, 41]. Below the thermocline, copepods were dominant both in number and biomass.

Our results, showing that the most abundant copepods were Clausocalanus spp., Paracalanus parvus, Centropages typicus, Temora stylifera, Oncaea spp., Corycaeus spp and Oithona plumifera, agree with observations made during summer by Gaudy [16-19] and Kouwenberg [27] in the Gulf of Lions. Microsetella rosea, a small harpacticoid very abundant in stomach contents of anchovies (PM 95), was very rare in samples collected with a $200 \mu \mathrm{m}$ net. In fact, Microsetella rosea, which has a spindle-shaped body with small appendages, is not well retained by the $200 \mu \mathrm{m}$ mesh. During PM 96, the use of a $80 \mu \mathrm{m}$ net demonstrated that this species was abundant (10 to 219 ind. $\cdot \mathrm{m}^{-3}$ ), which agrees with Dugas and Koslow's [12] findings. Candacia armata, a large copepod, was frequent at low densities.

\subsection{Feeding activity and estimation of food consumption of anchovy}

Because of the vertical migration exhibited by anchovy, it is not surprising to find a large amount of copepods, abundant below the thermocline where anchovy spend the day, and few cladocerans and doliols, abundant above the thermocline, in anchovy stomach contents.

Studies of daily feeding activity of the European anchovy have shown either a daytime pattern of activity which peaks at dusk [34, 44, 45] or a diurnal and nocturnal activity with an occasional decrease between 21 h00 and $24 \mathrm{~h} 00$ (spawning hours), but no regular peak [7, 8]. Our results also showed obvious and continuous feeding activity during the day with no peak at a regular time. However, in PM 96, the feeding activity was higher in the afternoon than in the morning; values of the fullness index obtained at night seem to suggest that anchovy fed in early night and that feeding activity ceased later.
Assessment of daily food consumption gives different results according to the authors and to the year of the study for the same author. The extreme values range from $1.4 \%$ to $9.3 \%$ of the body weight [34] or from 7.7 to $23.8 \%$ [7]. Our results for food consumption $(3.4 \%$ and $3.9 \%$ of somatic body wet weight) assessed during daytime were similar to those given by Tudela and Palomera [44] for daily consumption $(3.9 \%)$. In our assessment, the food ingested during the first part of the night was not integrated; therefore, the consumption was underestimated and the daily ration would be higher.

The differences in food consumption estimated by various authors could be explained partly by the values of the evacuation rate $(\mathrm{R})$ used: 1.02 and 0.423 by Bulgakova [7] and Tudela and Palomera [44] respectively. However, the differences in food consumption and thus feeding behaviour of anchovy could also arise from differences in the trophic environment prevailing in the study areas: Azov Sea [34], Black Sea [7, 8] and Catalan Sea [44].

\subsection{Diet composition and feeding behaviour of adult anchovy}

Studies on the feeding behaviour of Engraulidae from different areas and at different seasons have shown that Engraulis capensis [23], Engraulis ringens [26], Engraulis mordax [9] and Engraulis encrasicolus [8, 34] are essentially zooplanktonophagous. In the Catalan Sea, Tudela and Palomera [45] found that European anchovy was strictly zooplanktivorous during summer. In the Gulf of Lions, during the season of main spawning, our results have demonstrated that $E$. encrasicolus fed exclusively on zooplankton, the main prey items being copepods and crustacean larvae.

Laboratory studies on the feeding behaviour of small pelagic fishes have shown two types of behaviour: filter-feeding and raptorial-feeding [3, 13, 20-22, 24, 29, 37, 47, 48]. Atlantic menhaden was strictly filterfeeder [13] but others fishes like pilchard, anchovy, herring and mackerel used the two mechanisms of feeding [3, 20-22, 24, 29, 37, 47, 48]. The mechanism used depended essentially on size and density of prey. Clupea harengus [3, 20-22] and Scomber japonicus [37] used biting when prey were in low density and 
filtration when prey were high in density. Sardinops sagax $[47,48]$ was a filter-feeder on small prey present in both low and high density and on large prey present in high density. Pilchard used the raptorialfeeding only on large prey present in low density. Herring, pilchard and mackerel used preferentially the filter-feeding. Engraulis mordax [26] and Engraulis capensis [21] were filter-feeders on small prey and raptorial-feeders on large prey whatever the level of food concentration (above a threshold concentration), but they often used raptorial feeding.

After analysing the ratio prey-diameter/prey-length for northern anchovy feeding under natural conditions, Chiappa-Carrara and Gallardo-Gabello [9] concluded that filter-feeding was used for prey $<1.5$ $\mathrm{mm}$, and biting for prey $>1.5 \mathrm{~mm}$. Similarly, Bulgakova [8] concluded that inert items such as phytoplankton, copepod eggs and veligers were ingested by filtration, and larger swimming prey such as adult copepods and fish larvae were caught by raptorial feeding.

In our study, the usual feeding behaviour of adult anchovy, i.e. filtration on small prey and predation on large prey, was observed. Microsetella rosea $(0.8$ $\mathrm{mm}$ ), which was very abundant in stomach contents of anchovy $<12 \mathrm{~cm}$ (PM 95) and anchovy $<13.0$ cm (PM 96), was also abundant in the field suggesting filter feeding by small anchovy. And Candacia armata $(2.5 \mathrm{~mm})$, rare in plankton samples, was an important prey of anchovy $>13 \mathrm{~cm}$, suggesting selective feeding by large anchovy. However, this selective mechanism could be developed by small anchovy as demonstrated by the occurrence of large and active prey (Mallacostracean larvae) in stomach contents of $11.5 \mathrm{~cm}$ anchovies. These two mechanisms, filtration and predation appear to be mainly developed in small and large European anchovy, respectively.

\section{Acknowledgements}

We would like to thank Bernard Liorzou and Yvon Guennegan for their help during cruises and the reviewers for their constructive comments. This work was supported in part by IFREMER and Région Provence-Alpes-Côtes-d'Azur.

\section{REFERENCES}

[1] Aldebert Y., Tournier H., La reproduction de la sardine et de l'anchois dans le golfe du Lion, Rev. Trav. Inst. Pêches mar. 35 (1971) 57-75.

[2] Bakun A., Patterns in the ocean, Ocean processes and marine population dynamics, California Sea Grant College System, NOAA, Centro de Investigaciones Biológicas del Noroeste, La Paz, BCS México, 1996, 323 p.

[3] Batty R.S., Blaxter J.H.S., Richard J.M., Light intensity and feeding behaviour of herring, Clupea harengus, Mar. Biol. 107 (1990) 383-388.

[4] Baxter J.L., Summary of Biological Information on the Northern anchovy Engraulis mordax Girard, Calif. Coop. Oceanic. Fish. Invest., Prog. Rept. 1 July 1963 to 30 June 196611 (1967) 110-116.

[5] Blaxter J.H.S., Hunter J.R., The biology of clupeoid fishes, Adv. Mar. Biol. 20 (1982) 1-223.

[6] Bourdillon A., Quelques aspects du problème de l'échantillonnage du plancton marin, Terre Vie 1 (1964) 77-93.

[7] Bulgakova Y.V., Intensity of feeding of the Black Sea anchovy, Engraulis encrasicolus, during the spawning period, J. Ichthyol. 32 (1992) 146-151.

[8] Bulgakova Y.V., Daily feeding dynamics of the Black Sea anchovy, Engraulis encrasicholus, J. Ichthyol. 33 (1993) 78-88.

[9] Chiappa-Carrara X., Gallardo-Cabello M., Feeding behavior and dietary composition of the Northern anchovy, Engraulis mordax Girard (Pisces: Engraulidae) off Baja California, Mexico, Cienc. mar. 19 (1993) 285-305.

[10] Cleveland W.S., Devlin S.J., Locally Weighted Regression: An Approach to Regression Analysis by Local Fitting, J. Am. Stat. Assoc. 83 (1988) 596-610.

[11] Costello M.J., Predator feeding strategy and prey importance: a new graphical analysis, J. Fish Biol. 36 (1990) 261-263.

[12] Dugas J.C., Koslow J.A., Microsetella norvegica: a rare report of a potentially abundant copepod on the Scotian Shelf, Mar. Biol. 84 (1984) 131-134.

[13] Durbin A.G., Durbin E.G., Grazing rates of the Atlantic Menhaden Brevoortia tyrannus as a function of particle size and concentration, Mar. Biol. 33 (1975) 265-277.

[14] Elliott J.M., Persson L., The estimation of daily rates of food consumption for fish, J. Anim. Ecol. 47 (1978) 977-991.

[15] FAO, Fishery statistics Catches and landings vol. 78 1994, FAO Fish. Ser. 46 (1996) 310-311.

[16] Gaudy R., Biologie des copépodes pélagiques du golfe de Marseille, Rec. Trav. St. Mar. Endoume 27 (1962) 93-184.

[17] Gaudy R., Contribution à l'étude du cycle biologique des Copépodes du golfe de Marseille I. Environnement physique et biotique et la composition de la population de Copépodes, Téthys 3 (1971) 921-942.

[18] Gaudy R., Contribution à la connaissance du cycle biologique des Copépodes du golfe de Marseille II. Étude du cycle 
biologique de quelques espèces caractéristiques, Téthys 4 (1972) $175-242$.

[19] Gaudy R., Features and peculiarities of zooplankton communities from the Western Mediterranean, in: Moraitou- Apostolopoulou M., Kiortsis V. (Eds.), Mediterranean marine ecosystems, Plenum Press, 1985, pp. 279-301.

[20] Gibson R.N., Ezzi I.A., Effect of particle concentration on filter- and particulate-feeding in the herring Clupea harengus, Mar. Biol. 88 (1985) 109-116.

[21] Gibson R.N., Ezzi I.A., Relative importance of prey size and concentration in determining the feeding bahaviour of the herring Clupea harengus, Mar. Biol. 107 (1990) 357-362.

[22] Gibson R.N., Ezzi I.A., The relative profitability of particulate- and filter-feeding in the herring, Clupea harengus $\mathrm{L}, \mathrm{J}$. Fish. Biol. 40 (1992) 577-590.

[23] James A.G., Feeding ecology, diet and field-based studies on feeding selectivity of the Cape anchovy Engraulis capensis Gilchrist, in: Payne A.I.L., Gulland J.A., Brink K.H. (Eds.), The Benguela and comparable ecosystems, S. Afr. J. mar. Sci. 5 (1987) 673-692.

[24] James A.G., Findlay K.P., Effect of particle size and concentration on feeding behaviour, selectivity and rates of food ingestion by the Cape anchovy Engraulis capensis, Mar. Ecol. Prog. Ser. 50 (1989) 275-294.

[25] King D.P.F., MacLeod P.R., Comparison of the food and the filtering mechanism of pilchard Sardinops ocellata and anchovy Engraulis capensis off South West Africa, 1971-1972, Investl. Rep. Sea Fish. Brch S. Afr. 111 (1976) 1-29.

[26] Konchina Y.V., Trophic status of the Peruvian anchovy and sardine, J. Ichthyol. 31 (1991) 59-72.

[27] Kouwenberg J.H.M., Copepod distribution in relation to seasonal hydrographics and spatial structure in the north-western Mediterranean (Gulf of Lions), Estuar. coast. Shelf Sci. 38 (1994) 69-90.

[28] Lee J.Y., Aldebert Y., Observation sur la reproduction des anchois dans le golfe du Lion, Rapp. Comm. int. Mer Médit. 19 (1968) 281-282.

[29] Leong R.J.H., O’Connell C.P., A Laboratory Study of Particulate and Filter Feeding of the Northern Anchovy (Engraulis mordax), J. Fish. Res. Bd. Canada 26 (1969) 557-582.

[30] Le Tourneau M., Contribution à l'étude des cladocères du plancton du golfe de Marseille, Rec. Trav. St. Mar. Endoume 22 (1961) 123-151.

[31] Longhurst A.R., The Clupeoid Resources of Tropical Seas, Oceanogr. Mar. Biol. Ann. Rev. 9 (1971) 349-385.

[32] Loukashkin A.S., On the diet and feeding behavior of the Northern anchovy, Engraulis Mordax (Girard), Proc. Calif. Acad. Sci. 37 (1970) 419-458.

[33] Marshall S., Elliott M., A comparison of univariate and multivariate numerical and graphical techniques for determining inter- and intraspecific feeding relationships in estuarine fish, J. Fish Biol. 51 (1997) 526-545.
[34] Mikhman A.S., Tomanovich L.V., The feeding of the Azov anchovy, Engraulis encrasicholus maeoticus, J. Ichthyol. 17 (1977) 240-244.

[35] Millot C., Wind induced upwellings in the Gulf of Lions, Oceanol. Acta 2 (1979) 261-274.

[36] Millot C., The Gulf of Lions' hydrodynamics, Cont. Shelf Res. 10 (1990) 885-894.

[37] O'Connell C.P., Zweifel J.R., A laboratory study of particulate and filter feeding of the pacific mackerel, Scomber japonicus, Fish. Bull. 70 (1972) 973-981.

[38] Palomera I., Vertical distribution of eggs and larvae of Engraulis encrasicolus in stratified waters of the western Mediterranean, Mar. Biol. 111 (1991) 37-44.

[39] Palomera I., Spawning of anchovy Engraulis encrasicolus in the Northwestern Mediterranean relative to hydrographic features in the region, Mar. Ecol. Prog. Ser. 79 (1992) 215223.

[40] Palomera I., Sabatés A., Co-occurence of Engraulis encrasicolus and Sardinella aurita eggs and larvae in the northwestern Mediterranean, Sci. Mar. 54 (1990) 61-67.

[41] Patriti G., Les cladocères des milieux portuaires de Marseille, Mar. Biol. 20 (1973) 50-57.

[42] Razouls C., Kouwenberg J.H.M., Spatial distribution and seasonal variation of mesozooplankton biomass in the Gulf of Lions (Northwestern Mediterranean), Oceanol. Acta 16 (1993) $393-401$.

[43] Tournier H., Hydrologie saisonnière du golfe du Lion (Travaux de 'l'Ichthys' 1966-1967), Rev. Trav. Inst. Pêches mar. 33 (1969) 265-300.

[44] Tudela S., Palomera I., Diel feeding intensity and daily ration in the anchovy Engraulis encrasicolus in the Northwest Mediterranean Sea during the spawning period, Mar. Ecol. Prog. Ser. 129 (1995) 55-61.

[45] Tudela S., Palomera I., Trophic ecology of the European anchovy Engraulis encrasicolus in the Catalan Sea (Northwest Mediterranean), Mar. Ecol. Prog. Ser. 160 (1997) 121-134.

[46] Valdés-Szeinfeld E., The energetics and evolution of intraspecific predation (egg cannibalism) in the anchovy Engraulis capensis, Mar. Biol. 115 (1993) 301-308.

[47] van der Lingen C.D., Effect of particle size and concentration on the feeding behaviour of adult pilchard Sardinops sagax, Mar. Ecol. Prog. Ser. 109 (1994) 1-13.

[48] van der Lingen C.D., Respiration rate of adult pilchard Sardinops sagax in relation to temperature, voluntary swimming speed and feeding behaviour, Mar. Ecol. Prog. Ser. 129 (1995) 41-54.

[49] Worobec M.N., Field estimates of the daily ration of winter flounder, Pseudopleuronectes americanus (Walbaum), in a Southern New England Salt Pond, J. Exp. Mar. Biol. Ecol. 77 (1984) 183-196. 